\title{
Građevni i urbanistički propisi u Hrvatskoj od 1956. do 1971. godine
}

\author{
DARKO KAHLE \\ Essen, Savezna Republika Njemačka \\ darko.kahle@gmail.com
}

U članku se opisuju i komparativno analiziraju građevni i urbanistički propisi u Hrvatskoj od 1956. do 1971., kad je načelno dovršen zakonodavni okvir jugoslavenskih i hrvatskih građevnih propisa. Analizirani propisi, koji su prvi put bili stručno publicirani u repetitoriju 1956. godine, ambivalentno su nastajali na službenoj negaciji građevnoga zakonodavstva Kraljevine Jugoslavije 1946. i neslužbenom korištenju većine ukinutih propisa sve do kraja 1960-ih. Kolokvijalno poznati pod suvremenim pojmom građevinska regulativa, analizirani propisi pokazuju određenu tehničku kompetentnost u člancima koji nisu zadirali u socijalističko društveno uređenje, ali i potpunu ovisnost o tom uređenju u ostalim paragrafima, poput procedura upravnoga postupka ili toleriranja bespravne izgradnje.

Ključne riječi: građevno zakonodavstvo; građevni propisi; urbanistički propisi; $\mathrm{Hr}$ vatska; Zagreb; 1956. - 1971.; građevinska regulativa

\section{Uvod}

Ovim znanstvenim člankom zaključena je analiza građevnih propisa grada Zagreba od revolucije 1848./1849. pa sve do kraja Hrvatskoga proljeća 1971. godine. Dosad su objavljeni članci „Građevinski propisi grada Zagreba u razdoblju od 1850. do 1918. godine” (2004.) ${ }^{1}$, „Građevinski propisi za grad Zagreb u razdoblju od 1919. do 1931. godine i Građevinski zakon iz 1931. go-

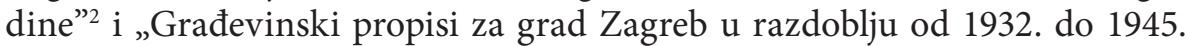
godine” (2006.) ${ }^{3}$ te „Rasprava 'Djelovanje potresa na zgrade' akademika Andrije Mohorovičića iz 1911. godine i protupotresna analiza građevnih propi-

1 KAHLE, „Građevinski propisi grada Zagreba u razdoblju od 1850. do 1918. godine”, 203-215.

2 KAHLE, „Građevinski propisi za grad Zagreb u razdoblju od 1919. do 1931. godine i Građevinski zakon iz 1931. godine”, 116-129.

3 KAHLE, „Građevinski propisi za grad Zagreb u razdoblju od 1932. do 1945. godine”, 218-227. 
sa grada Zagreba u razdoblju od 1857. do 1964. godine" (2020.). ${ }^{4}$ Zagrebački su građevni propisi u prva tri članka analizirani u razdoblju između 1850. i 1945., a u četvrtom su analizirani u kontekstu protupotresne zaštite uzrokovane recentnim potresima 2020. godine. Analiza zagrebačkih građevnih propisa ovim je člankom protegnuta na državno područje Republike Hrvatske, u današnjim granicama od 5. listopada 1954. nakon priključenja dijelova bivšega Slobodnog Teritorija Trsta ${ }^{6}$ Federativnoj Narodnoj Republici Jugoslaviji (FNRJ) i Narodnoj Republici Hrvatskoj (NRH). Jugoslavenska država preimenovana je 10. travnja 1963. u Socijalističku Federativnu Republiku Jugoslaviju $(\mathrm{SFRJ})^{7}$, a hrvatska u Socijalističku Republiku Hrvatsku (SRH) ${ }^{8}$, koja se od 24. srpnja 1990. zove Republika Hrvatska, 8. listopada 1991. postaje samostalna država, a 1. srpnja 2013. punopravna članica Europske unije.

Kao primarni izvori korišteni su autentični tekstovi zakona i propisa objavljeni u službenim državnim glasilima između 1848. i 1971., odnosno sve do 1990. godine. Za razdoblje Austrijske Carevine (1848. - 1867.), odnosno Austro-Ugarske Monarhije (1867. - 1918.) velika većina zakonskih tekstova može se pronaći na mrežnoj stranici Austrijske nacionalne biblioteke (Österreichische Nationalbibliothek) u digitalnoj zbirci ALEX, Povijesni pravni i zakonski tekstovi. ${ }^{9}$ Za Austrijsku Carevinu između 1848. i 1867. izlazilo je službeno glasilo na njemačkom jeziku ${ }^{10}$, od 1849. do 1852. na hrvatskom jeziku pod naslovom Sveobći deržavo-zakonski i vladni list za Carevinu Austriansku, a za Cislajtaniju kao sastavni dio Monarhije između 1868. i 1918. na njemačkom jeziku, a od 1870. do 1918. i na hrvatskom jeziku kao Dèržavo-zakonski list za kraljevine i zemlje, zastupane u vieću cesarevinskom. ${ }^{11} \mathrm{Za}$ krunovinu, kasnije kraljevine Hrvatsku i Slavoniju u razdoblju 1850. - 1918. izlazio je zbornik zakona na hrvatskom jeziku. ${ }^{12}$ Za krunovinu, kasnije kraljevinu

4 KAHLE, „Rasprava 'Djelovanje potresa na zgrade' akademika Andrije Mohorovičića iz 1911. godine i protupotresna analiza građevnih propisa grada Zagreba u razdoblju od 1857. do 1964. godine", 29-42.

5 Dalje zbog jednostavnosti za cijelo državno područje koristim termin teritorij Hrvatske.

6 Tzv. Londonskim memorandumom. Vidi: Memorandum of Understanding (with annexes and exchange of notes) regarding the Free Territory of Trieste. Signed at London, on 5 October 1954.

7 Službeni list Socijalističke Federativne Republike Jugoslavije (Beograd), 14 (1963).

8 Narodne novine: službeni list Socijalističke Republike Hrvatske (Zagreb), 15 (1963).

9 Austria Lex, Historische Rechts- und Gesetzestexte.

10 ALEX, Reichs-, Staats- und Bundesgesetzblätter.

11 ALEX, Reichsgesetzblatt Kroatisch, godište 1913. nije digitalizirano.

12 ALEX, Landesgesetzblätter für Kroatien und Slavonien, godišta 1860. - 1863., 1865. 1867., 1872. i 1890. nisu digitalizirana. - U ALEX-u za krunovinu (1848. - 1852.), kasnije kraljevinu Ugarsku (1852. - 1867.) postoje zakoni na njemačkom jeziku samo do kraja 1859. dakle do pada Bachova apsolutizma. Drugim riječima, austrijska pravna historiografija kraljevine Hrvatsku i Slavoniju smatra i austrijskim provincijama sve do dezintegracije Monarhije krajem 1918. godine. Kako je Rijeka u austrougarskom razdoblju bila sastavni dio Ugarske odvojen od Hrvatske i Slavonije, a između dva svjetska rata sastavni dio Kraljevine Italije, za preciznu povijest njezinih građevnih propisa od 1867. do 1947. trebalo bi detaljno pregledati mađarske, Antantine, talijanske, nacističke i savezničke arhive. 
Dalmaciju u razdoblju 1848. - 1859. izlazio je zbornik zakona na hrvatskom, njemačkom i talijanskom jeziku, između 1860. i 1918. na njemačkom jeziku ${ }^{13}$, a za Trst i Priobalje (Küstenland) od 1851. do 1918. na njemačkom, talijanskom i slovenskom jeziku. ${ }^{14}$ U razdoblju Države Slovenaca, Hrvata i Srba, od 1. prosinca 1918. Kraljevstva Srba, Hrvata i Slovenaca, odnosno od 3. listopada 1929. Kraljevine Jugoslavije izlazilo je službeno državno glasilo Službene novine, koje je nakon kapitulacije Jugoslavije u Travanjskom ratu 1941. nastavilo izlaziti u egzilu u Londonu do 25. listopada 1944., kad je u posljednjem broju bio objavljen Sporazum izmedju Kraljevske vlade i Nacionalnog komiteta oslobodjenja Jugoslavije, to jest sporazum Šubašić-Tito. Stari monarhijski zbornik zakona za Hrvatsku i Slavoniju nastavio je s izlaženjem do Vidovdanskoga ustava 1921. godine. ${ }^{15}$ Po uspostavi banovina 1929. Narodne novine postale su službeno glasilo Savske banovine, a nakon sporazuma Cvetković-Maček 1939. službeno glasilo novoformirane Banovine Hrvatske. ${ }^{16}$ Nakon osnivanja Države Hrvatske 10. travnja 1941., od 29. travnja iste godine Nezavisne Države Hrvatske (NDH), Narodne novine Nezavisne Države Hrvatske postaju službeno državno glasilo sve do formalne predaje oružanih snaga na Blajburškom polju 15. svibnja 1945. godine. ${ }^{17} \mathrm{U}$ razdoblju Demokratske Federativne Jugoslavije (DFJ, 1944. - 1945.) započelo je 1. veljače 1945. izdavanje službenoga državnoga glasila pod nazivom Službeni list Demokratske Federativne Jugoslavije, od 30. studenog 1945. Službeni list Federativne Narodne Republike Jugoslavije (dalje: SL FNRJ), od 10. travnja 1963. Službeni list Socijalističke Federativne Republike Jugoslavije (dalje: SL SFRJ) sve do 27. 4. 1992. godine. Nakon propasti NDH u Zagrebu je 1945. obnovljeno izdavanje službenoga glasila pod imenom Narodne novine: službeni list Federalne Hrvatske, od veljače 1946. Narodne novine: službeni list Narodne Republike Hrvatske (dalje: NN NRH), od 10. travnja 1963. Narodne novine: službeni list Socijalističke Republike Hrvatske (dalje: NN SRH) do 28. srpnja 1990., kad su preimenovane u Narodne novine: službeni list Republike Hrvatske (dalje: NN RH), od 8. listopada 1991. službeno državno glasilo.

Kao sekundarna stručna literatura korišteni su priručnici u kojima su stručnjaci pravne ili tehničke struke prikazivali pojedine zakone odnosno zbirke zakona sa stručnim tumačenjima pojedinih zakonskih članaka. Za razdoblje 1848. - 1918. važan je Priručnik za političku upravnu službu u kralje-

13 ALEX, Landesgesetzblätter für Dalmatien, godište 1848. nije digitalizirano.

14 ALEX, Landesgesetzblätter für Triest und das Küstenland. Godišta su digitalizirana uvijek na njemačkom, pretežno na njemačkom i talijanskom, rjeđe na sva tri jezika.

15 Godište 1919., u kojem se nalazi „Naredba o osnivanju Tehničke visoke škole u Zagrebu", nije digitalizirano u ALEX-u, kao ni godišta 1920. i 1921., a postoji mogućnost da je izašlo i 1922. godište.

16 KAHLE, „Architectural Legislative Jurisdictions of the Banovina of Croatia (1939-1941) and the Independent State Of Croatia (1941-1945)", 26.

17 SISTORY, Zgodovina Slovenije, Uradni listi, Uradni listi iz obdobja 1941-1945, Zakoni, zakonske odredbe i naredbe Nezavisne Države Hrvatske. Digitalizirano je razdoblje od 11. 4. 1941. do kraja 1944. godine. 
vinah Hrvatskoj i Slavoniji autora Milana Smrekara. ${ }^{18}$ U razdoblju od 1919. do 1945. valja izdvojiti Građevinski zakon: sa uredbama, propisima i normama za njegovo izvršenje. Drugo izdanje ${ }^{19}$, odnosno Zakon o ovlašćenim inženjerima: sa komentarom i dodatkom. ${ }^{20} \mathrm{Za}$ razdoblje socijalističke Jugoslavije od 1946. do 1971. ključan je stručni „Repetitorij građevnih propisa i procedure u N. R. Hrvatskoj" Vladimira Šilharda. ${ }^{21}$ Između 1945. i 1990. kontinuirano su izlazili stručni priručnici s komentarima građevnih propisa, na primjer Zbirka tehničkih propisa iz oblasti građevinarstva ${ }^{22}$, Zbirka tehničkih propisa (tehničkih uslova, mera i normativa) u građevinarstvu ${ }^{23}$, Zaštita od požara: izbor saveznih propisa s komentarom ${ }^{24}$, Zakonodavstvo urbanizma, arhitekture, baštine, čovjekove sredine, prostornog uređenja ${ }^{25}$, odnosno Visokogradnja. Zbirka građevinskih propisa visokogradnje i niskogradnje za beton, drvo, čelik, mostogradnju sa kompletnim jugoslovenskim standardima ${ }^{26} \mathrm{U}$ novije vrijeme objavljen je priručnik Sustavi planiranja korištenja zemljišta - povijesni prikaz, postojeće stanje, prijedlog mogućeg oblikovanja hrvatskog sustava korištenja zemljišta Vladimira Krtalića. ${ }^{27}$ Prikaz sekundarne znanstvene literature počinje poticajnim člankom „Analiza urbanističko-komunalnih i graditeljskih regula u srednjovjekovnom statutu grada Iloka iz 1525. godine" autora Zlatka Karača i Alana Brauna, u kojem se definira položaj građevnih propisa u srednjovjekovnom statutu hrvatskoga grada, nadalje se taksativno navode gradovi jadranskoga dijela Hrvatske koji su imali gradski statut, a informativno spominju gradovi kontinentalnoga dijela Hrvatske s vladarskim poveljama. Zaključno se navode znanstveni radovi koji analiziraju srednjovjekovne građevne propise za pojedine gradove. ${ }^{28} \mathrm{U}$ spomenutim člancima autora Darka Kahlea detaljno je analizirano građevno zakonodavstvo u razdoblju 1850. - 1945., ali je prikaz teritorijalno ograničen na područje grada Zagreba. Analiza neprihvaćenih građevinskih redova za grad Zagreb s kraja XIX. odnosno početka XX. stoljeća nalazi se u članku Zlatka Jurića „Građevni redovi i regulatorno planiranje Zagreba od 1900. do 1918. godine”. ${ }^{29}$ Dosad nepoznata građa važna za

18 SMREKAR, Priručnik za političku upravnu službu u kraljevinah Hrvatskoj i Slavoniji, knj. 3, Poglavje četvrto. Gradjevno redarstvo. I. Gradjevni redovi. 1. Gradjevni red za ladanje, 488-518; ISTI, Gradjevni red za okolicu Plitvičkih jezera, 514-520 (tekst u bilješci); 2. Gradjevni red za gradove, 520-548; 3. Gradjevni red za grad Zagreb, 548-569; II. Propisi o izvlastbi, 570-605.

19 NIKETIĆ, Građevinski zakon, 7-75.

20 KOVAČEVIĆ, Zakon o ovlašćenim inženjerima, 6-144.

21 ŠILHARD, „Repetitorij građevnih propisa i procedure u N. R. Hrvatskoj”, 9-10.

22 POP-KOCIĆ, Zbirka tehničkih propisa iz oblasti građevinarstva, 5-441.

23 B. FURUNDŽIĆ, S. FURUNDŽIĆ, Zbirka tehničkih propisa, $1 \mathrm{ff}$.

24 MAROVIĆ, ATEVIĆ, Zaštita od požara, 7-441.

25 KRSTIĆ, PAJOVIĆ, Zakonodavstvo urbanizma, arhitekture, baštine, čovjekove sredine, prostornog uređenja, $1 \mathrm{ff}$.

26 VINCEKOVIĆ et al., Visokogradnja, knj. 2: 93-97, knj. 3: 5-8, knj. 4: 99-105.

27 KRTALIĆ, Sustavi planiranja korištenja zemljišta, $1 \mathrm{ff}$.

28 KARAČ, BRAUN, „Analiza urbanističko-komunalnih i graditeljskih regula u srednjovjekovnom statutu grada Iloka iz 1525. godine", 15.

29 JURIĆ, „Građevni redovi i regulatorno planiranje Zagreba od 1900. do 1918. godine”, 35. 
položaj arhitekata u Dalmaciji prikazana je i analizirana u članku „Ovlašteni arhitekti i strukovna udruženja u Dalmaciji do 1941. godine” Jasenke Kranjčević. ${ }^{30}$ Razvoj pravnoga sustava u Hrvatskoj krajem Drugoga svjetskog rata odgovarajuće je prikazan u članku „Razvoj pravosudnih vlasti i odgovarajućega pravnog okvira u Hrvatskoj 1945. godine” Martine Grahek Ravančić. ${ }^{31}$ Odnos zagrebačke stanogradnje prema urbanističkim planovima prikazan je u članku Lidije Bencetić „Zagrebačka stanogradnja u prijedlozima planova i generalnim urbanističkim planovima od 1945. do 1990.”32 Prikaz sekundarne znanstvene literature zaključuje dvojezični članak „Urban planning in socialist Croatia / Urbano planiranje u Hrvatskoj tijekom socijalističkoga režima” autorskoga trojca Neven Tandarić, Charles Watkins i Christopher D. Ives. ${ }^{33}$

\section{Metodologija}

U članku je primijenjena metoda komparativne analize važećih građevnih propisa na teritoriju Hrvatske kao primarni izvor istraživanja, to jest zakonskih i podzakonskih tekstova savezne i hrvatske republičke razine objavljenih u Službenom listu FNRJ/SFRJ i Narodnim novinama NRH/SRH. Analiza je obuhvatila razdoblje između 1956. i 1971., odnosno od objave repetitorija građevnih propisa $\mathrm{NRH}^{34}$ do propasti Hrvatskoga proljeća. Valja napomenuti da je teritorij Hrvatske bio kompletiran tek u listopadu 1954. formalnim pripajanjem hrvatskoga dijela ukinutoga Slobodnog Teritorija Trsta. Detaljno su analizirani građevni propisi i zakoni prethodnoga razdoblja, počevši od 1946., zbog usporedbe razdoblja tzv. administrativne planske privrede (1945. - 1955.) s razdobljem tzv. privrede društvenih fondova za kreditiranje stambene izgradnje (1955. - 1965.) te nastavno s razdobljem tzv. tržišne stambene privrede (1965. - 1975.). ${ }^{35} \mathrm{Na}$ početku su ukratko prikazani i analizirani građevni propisi građanskoga društvenog sustava između 1848. i 1945. u onodobnim zemljama i područjima na teritoriju Hrvatske, iako je za detaljnu analizu toga razdoblja potreban zaseban znanstveni rad. U prilogu je naveden popis građevnih propisa donesenih i važećih na teritoriju Hrvatske između 1946. i 1971. prema primarnim izvorima.

${ }^{30}$ KRANJČEVIĆ, „Ovlašteni arhitekti i strukovna udruženja u Dalmaciji do 1941. godine", 207.

${ }^{31}$ GRAHEK RAVANČIĆ, „Razvoj pravosudnih vlasti i odgovarajućega pravnog okvira u Hrvatskoj 1945. godine”, 157.

32 BENCETIĆ, „Zagrebačka stanogradnja u prijedlozima planova i generalnim urbanističkim planovima od 1945. do 1990.", 389.

33 TANDARIĆ, WATKINS, IVES, „Urban planning in socialist Croatia / Urbano planiranje u Hrvatskoj tijekom socijalističkoga režima”, 5.

34 ŠILHARD, „Repetitorij građevnih propisa i procedure u N. R. Hrvatskoj”, 9.

35 MRČELA, „Neki aspekti odnosa ponuda i potražnje u stanogradnji Jugoslavije od 1945. do danas", 13. 
Građevno zakonodavstvo zemalja i područja na teritoriju današnje Hrvatske između 1848. i 1945. godine

Kako je u ovom članku teritorijalni opseg analiziranih zakona i propisa proširen s područja grada Zagreba na cjelokupno hrvatsko državno područje, potrebno je ukratko prikazati građevne propise relevantnih povijesnih jurisdikcija na područjima koja čine teritorij Hrvatske. Sva ta područja našla su se najkasnije 1815. u jednoj državi, to jest u Austrijskom Carstvu, ali je područje istočne Istre do vrha Učke s Pazinom zakonodavno spadalo u Sveto Rimsko Carstvo Njemačke Narodnosti do 1806., poslije u Njemački Savez ${ }^{36}$, ostatak Istre u Kraljevinu Iliriju, Dalmacija od Starigrada do Prevlake uključujući bivšu Dubrovačku Republiku, ukinutu 1806., u Kraljevinu Dalmaciju, Baranja i Međimurje u Kraljevinu Ugarsku, a ostatak hrvatskoga teritorija uživao je autonomiju u realnoj uniji s Kraljevinom Ugarskom pod nazivom Kraljevina Hrvatska i Slavonija, umanjena za Vojnu krajinu pod izravnom carskom vojnom upravom. Sve te jurisdikcije imale su feudalno ustrojstvo građevnoga zakonodavstva, s gradskim statutima odnosno vladarevim poveljama, od kojih je svaki pojedini sadržavao relevantne odredbe o planiranju, regulaciji i građenju. ${ }^{37} \mathrm{Na}$ primjer, Dubrovački statut već je prilikom donošenja 1272. sadržavao odredbe o građenju, koje su 1333. bile primijenjene na izgradnju novoga grada Stona. ${ }^{38}$ Nezadovoljstvo dijela europskih naroda i pučanstva dovelo je do revolucije 1848./1849. u Njemačkom Savezu, Carevini Austriji i drugdje. Nakon propasti revolucije 1849. Carevina je uređena na centralističkom principu, uz uvažavanje osobnih sloboda i ukidanje kmetstva. Jedan od pobjedničkih generala, ban Hrvatske i Slavonije, barun Josip Jelačić bio je postavljen za zapovjednika Dalmacije i Vojne krajine te guvernera Rijeke, čime su hrvatske povijesne zemlje bile personalno ujedinjene sve do njegove smrti 1859. godine. Godine 1849. pokrenuto je izdavanje službenoga državnoga glasila Carevine na njemačkom i ostalim službenim jezicima, među kojima i na hrvatskom, ali je nakon smrti ministra predsjednika princa Felixa Schwarzenberga 1852. nastavljeno izdavanje samo na njemačkom jeziku. Otpisom cara Franje Josipa I. 1850. ozakonjen je Propis o prijetju graditeljstvenih pitomacah i o uvedenju deržavnih izpitah za one, koji kod graditeljstva služiti žele ${ }^{39} \mathrm{kao}$

\footnotetext{
36 Der Deutsche Bund u razdoblju 1815. - 1866.

37 KARAČ, BRAUN, „Analiza urbanističko-komunalnih i graditeljskih regula u srednjovjekovnom statutu grada Iloka iz 1525. godine", 15.

38 PRELOG, „Dubrovački statut i izgradnja grada (1272-1972)”, 81.

39 U njemačkom izvorniku „Erlass der Handelsministeriums vom 13. März 1850, ..., womit die mit allerhöchster Entschliessung Sr. Majestät genehmigte 118. [']Vorschrift über die Aufnahme von Bau-Eleven und die Einführung von Staatsprüfungen für den Baudienst['] kundgemacht wird". In: Allgemeines Reichs-Gesetz- und Regierungsblatt für das Kaiserthum Oesterreich, XXXIII. Stück, Ausgegeben und versendet in der deutschen Allein-Ausgabe am 28. März 1850, in der gegenwärtigen Doppel-Ausgabe am 13. Mai 1850., 704-707. U hrvatskom izdanju: „Razpis Ministarstva tèrgovine od 13. ožujka 1850, .., kojom [sic!] se proglašuje previšnjom odlukom nj. Veličanstva odobreni 118. ['P]ropis o prijetju graditeljstvenih pitomacah i o uvedenju dèržavnih izpitah za službu kod graditeljstva[']...", u: Sveobći dèržavno-zakonski
} 
prvi zajednički austrijski zakon koji je propisivao tehničku izobrazbu budućih državnih službenika građevne struke u visokim tehničkim školama po kurikulumu koji se recentno označava pojmom STEM, čime je započeto izuzimanje tehničke (graditeljske) struke iz jurisdikcije općega (civilnoga) pravnog sustava. Hrvatska pokrajinska vlada oktroirala je 1. veljače 1857. Građevni red (Bauordnung) za zemaljski glavni grad Zagreb (Landeshauptstadt Agram), kojim je među ostalim propisana procedura izdavanja odobrenja za gradnju te uporabu za svako građenje, odnosno veću rekonstrukciju, a za provedbu toga procesa bilo je određeno zasebno stručno gradsko tijelo. ${ }^{40}$ Pokrajinska vlada Austrijsko-ilirskoga primorja (među ostalim Istra) otpisom od 12. rujna 1861., a Pokrajinska vlada Dalmacije okružnicom od 12. siječnja 1864. (oba propisa samo na njemačkom jeziku), uvela je ovlaštene (behördlich autorisirten) privatne tehnike (Privat-Technikern), i to: 1. civilne inženjere svih građevnih struka, 2 . arhitekte i 3 . geodete. ${ }^{41}$ Austro-ugarskom nagodbom iz 1867. uveden je dualizam, to jest osnivanje dviju zasebnih država koje se zbog kompliciranih službenih, odnosno poluslužbenih naziva neformalno zovu Cislajtanija (Austrija, od hrvatskih zemalja Istra do Rijeke, odnosno Dalmacija od Starigrada do Prevlake) i Translajtanija (Ugarska, od hrvatskih zemalja kraljevine Hrvatska i Slavonija s Vojnom krajinom, Rijeka odnosno Baranja i Međimurje), svaka sa zasebnim zakonodavstvom, uključujući zasebne građevne propise i zasebno državljanstvo. Ugarsko-hrvatskom nagodbom 1868. kraljevine Hrvatska i Slavonija zadržale su potpunu autonomiju u poslovima građevne uprave nadležnim za privatno graditeljstvo, odnosno za one zgrade i građevine koje su ostale u okviru autonomije - školstvo, zdravstvo, općinska i državna (pokrajinska) uprava, županijske i državne ceste, mostovi i rijeke. Željeznice, pošte, luke i rudnici spadali su pod državnu ingerenciju zajedničke ugarsko-hrvatske države (Translajtanije), a vojne zgrade i građevine (vojarne, fortifikacije, strateške željezničke pruge itd.) spadale su pod zajedničku austro-ugarsku državu, odnosno Habsburšku Monarhiju, i u tom području njemački jezik ostao je službeni sve do 1918. godine. U pokrajinama austrijskoga dijela Monarhije donesen je 1874. Red građenja (Bauordnung) za Austro-ilirsko primorje, uključujući Istru i Opatiju s Voloskim ${ }^{42}$, a 1886. za Dalmaciju. ${ }^{43}$ Za cijelu Cislajtaniju donesen je 1913. Zakon o uspostavi i uređenju inženjerskih komora ${ }^{44}$, ali zbog početka Prvoga svjetskog rata nije bio primijenjen sve do raspada Monarhije. U Hrvatskoj i Slavoniji donesena je 1877. Naredba,

i vladni list za Carevinu Austriansku, komad XXXIII., izdan i razposlan u niemačkom samo-izdanju 28. ožujka 1850., u ovom dvostrukom izdanju 13. svibnja 1850., 704-707.

40 ALEX, Landesgesetzblätter für Kroatien und Slavonien, god. 1857., 2. Abt., 8-32.

${ }^{41}$ ALEX, Landesgesetzblätter für Triest und das Küstenland, god. 1861., 51-56; ALEX, Landesgesetzblätter für Dalmatien, god. 1864., 5-12.

42 ALEX, Landesgesetzblätter für Triest und das Küstenland, god. 1874., 11-26.

43 ALEX, Landesgesetzblätter für Dalmatien, god. 1886., 23-44. U njemačkom izvorniku: Landes-Gesetz und Verordnungsblatt für Dalmatien. V Stück. Ausgegeben und versendet am 10 April 1886. Gesetz von 15 Februar 1886, gültig für das Königreich Dalmatien, mit welchen eine Bauordnung eingeführt wird.

${ }^{44}$ ALEX, Reichs-, Staats- und Bundesgesetzblätter, god. 1913., 5-8. 
tičući se ovlašćivanja civilnih tehnikah, kojom su bili obuhvaćeni „1. civilni inžiniri, 2. arhitekti, 3. gradjevni mjernici i 4. mjernici i zemljomjeri." ${ }^{45}$ Godine 1899. propisan je [G]radjevni red za okolicu Plitvičkih jezera izmedju selah Leskovca i Plitvice ${ }^{46}$, a 1900. tri građevna reda: I. Gradjevni red za ladanje ${ }^{47}$, II. Gradjevni red za gradove ${ }^{48}$ i III. Gradjevni red za gradove Osiek, Varaždin $i$ Zemun. ${ }^{49}$ Godine 1911. donijeta je naredba ${ }^{50}$ kojom se „uredjuje djelokrug civilnih tehnika i postupak glede njihovoga ovlašćivanja”, kojom je de facto uvedeno komorsko uređenje ovlaštenih stručnjaka, prisega i ispit za ovlaštenje koji se održavao u Zagrebu sve do 1925. godine. ${ }^{51}$

Raspadom Austro-Ugarske Monarhije kao posljedica poraza u Prvom svjetskom ratu Hrvatski je sabor 28. listopada 1918. raskinuo stoljetne državnopravne veze s Austrijom i Ugarskom te pristupio novoosnovanoj privremenoj Državi Slovenaca, Hrvata i Srba, koja je 1. prosinca 1918. pristupila Kraljevini Srbiji, uvećanoj za Crnu Goru i Srpsku Vojvodinu, u Kraljevstvo Srba, Hrvata i Slovenaca. Istra, Rijeka, Zadar te otoci Cres, Lošinj i Lastovo pripali su Kraljevini Italiji i na tom dijelu teritorija Hrvatske vrijedili su talijanski građevni propisi sve do završetka Drugoga svjetskog rata, a najkasnije do ukidanja Slobodnoga Teritorija Trsta 1954. godine. Nova zajednička jugoslavenska država bila je pseudofederalna monarhija s postojanjem povijesnih pokrajina sve do proglašenja Vidovdanskoga ustava 28. lipnja 1921., čime je još otprilike dvije i pol godine od nestanka Austro-Ugarske formalno postojao njezin građevni pravni sustav. Tako je povjereniku Države Slovenaca, Hrvata i Srba uspjelo 10. prosinca 1918. u Kraljevstvu Srba, Hrvata i Slovenaca naredbeno osnovati Tehničku visoku školu u Zagrebu. To je kraljevstvo 1919. dobilo zasebno Ministarstvo građevina ${ }^{52}$, koje je bilo podijeljeno na osam direkcija (Beograd, Ljubljana, Zagreb, Split, Novi Sad i dr.). Stručni ispiti bili su najkasnije 1925. preseljeni u Beograd. ${ }^{53}$ Uredništvo službenoga glasila arhitekata i inženjera bilo je od 1919. do 1939. smješteno u Zagrebu. Unifikacijom i centralizacijom građevnoga zakonodavstva u prvom desetljeću postojanja prve jugoslavenske države prevladali su napredni interesi razvijenijih zapadnih dijelova. U takvim okolnostima u Zagrebu je 7. lipnja 1931. proglašen Gradevinski zakon [Kraljevine Jugoslavije] ${ }^{54}$, koji je stupio na snagu 16. prosinca

\footnotetext{
45 ALEX, Landesgesetzblätter für Kroatien und Slavonien, god. 1877., 677-687.

46 Isto, god. 1899., 489-501.

47 Isto, god. 1900., 465-496.

48 Isto, god. 1900., 497-532.

49 Isto, god. 1900., 582-616.

50 Isto, god. 1911., 364-438.

51 Rijeka zbog svojega posebnog položaja u Ugarskoj i kasnije pripadanja Italiji nije mogla biti obuhvaćena ovim pregledom.

52 „Uredba o ustrojstvu Ministarstva gradjevina”, 25-28.

53 KAHLE, „The Architectural Office Vladimir Šterk in the Period 1923-1941”, 24-25, bilj. 24.

54 Službene novine [Kraljevine Jugoslavije] (Beograd), broj 133-XLII, 16. 6. 1931.; Službene novine [Kraljevine Jugoslavije], broj 174-LVII, 3. 8. 1931.; KAHLE, „Građevinski propisi za grad Zagreb u razdoblju od 1919. do 1931. godine i Građevinski zakon iz 1931. godine”, 122 126.
} 
1931. i nakon formalnoga ukidanja 1946. bio neslužbeno korišten sve do kraja 1960-ih ${ }^{55}$, a 1937. Zakon o ovlaštenim arhitektima i inženjerima ${ }^{56}$, koji je na posve moderan način regulirao djelovanje samostalnih projektanata. ${ }^{57} \mathrm{Osni}$ vanjem Banovine Hrvatske 26. kolovoza 1939., kao rezultat dogovora Cvetković-Maček u aranžmanu Ujedinjenoga Kraljevstva Velike Britanije i Sjeverne Irske, a potaknuto izvjesnim početkom Drugoga svjetskog rata, građevni je sustav vraćen na stanje prije 28. lipnja 1921., odnosno 28. listopada 1918., iako su fundamentalni zakoni iz 1931. i 1937. ostali na snazi. ${ }^{58}$ Inženjerske komore u Zagrebu i Splitu ujedinjene su u Savez inženjerskih komora Banovine $\mathrm{Hr}$ vatske, a polaganje stručnih ispita vraćeno je u Zagreb. Nedugo nakon napada Njemačkoga Reicha na Kraljevinu Jugoslaviju 6. travnja 1941., proglašena je 10. travnja 1941. satelitska država pod nazivom Država Hrvatska, od 29. travnja s pridjevom Nezavisna, koja je uključila područje bivših banovina u Bosni i Hercegovini, ali bez Međimurja, Sušaka, Gorskoga kotara, gotovo svih otoka i dijela Dalmacije od Zadra do Splita. Time je u savez državnih inženjerskih komora bila kooptirana i Inženjerska komora u Sarajevu kao ispostava zagrebačke komore. Zakoni iz 1931. i 1937. ostali su na snazi ${ }^{59}$, ali je militarizacija i totalitarizacija društvenih odnosa koju je provodio kvislinški režim potpuno zakočila svaki napredak. Građenje se odvijalo uglavnom za ratne potrebe. Međutim, vlada Kraljevine Jugoslavije emigrirala je u London, gdje je predstavljala de iure postojeću jugoslavensku državu. Nadalje, partizanski pokret otpora, okupljen oko Komunističke partije Jugoslavije, donosio je vlastite propise na područjima pod svojom kontrolom, a 29. studenog 1943. na 2. zasjedanju AVNOJ-a u Jajcu proglasio novu jugoslavensku saveznu državu i uključio područja kojima je vladala upravo poražena Kraljevina Italija, dakle Zadar, Rijeku, Istru i Trst, u buduću državu. ${ }^{60}$ Sljedeće godine na području pod upravom Narodnooslobodilačke vojske Jugoslavije održan je seminar o urbanističkoj obnovi porušenih naselja Federalne Hrvatske pod vodstvom akademskoga arhitekta Nevena Šegvića, kojem zbog partizanskoga angažmana nije bilo dano projektantsko ovlaštenje u NDH, za razliku od braće Drage i Vlade Galića, Stjepana Planića, Lavoslava Horvata ili Antuna Ulricha. Nakon ulaska partizanskih postrojbi i Crvene armije u Beograd 20. listopada 1944., odnosno nakon drugoga susreta Tito-Šubašić, odlučeno je da se građevna

55 RUKAVINA, Zbirka najvažnijih propisa iz oblasti urbanizma i građevinarstva, sv. 3, 22.

56 Službene novine [Kraljevine Jugoslavije], broj 232-LXVIII, 13. 10. 1937.

57 Ta dva zakona pokazuju modernitet predmetnoga kraljevskoga jugoslavenskog zakonodavstva jer su bili pripremljeni konsenzusom tehničkih stručnjaka i političara te demokratski prihvaćeni u oba doma kraljevskoga parlamenta bez obzira na vladarevu (kraljevu) odnosno premijerovu (Stojadinovićevu) diktaturu. Za kasniji zakon usp. KOVAČEVIĆ, Zakon o ovlašćenim inženjerima, $1 \mathrm{ff}$.

58 KAHLE, „Architectural Legislative Jurisdictions of the Banovina of Croatia (1939-1941) and the Independent State Of Croatia (1941-1945)", 26.

59 KAHLE, „Građevinski propisi za grad Zagreb u razdoblju od 1932. do 1945. godine”, 218-227.

60 GRAHEK RAVANČIĆ, „Razvoj pravosudnih vlasti i odgovarajućega pravnog okvira u Hrvatskoj 1945. godine", 157-183. 
služba ponovno ujedini ${ }^{61}$, a privremena vlada DFJ osnovana u proljeće 1945. imala je Ministarstvo građevina - dakle, jugoslavenska građevna služba centralizirana je još u vrijeme legalnoga postojanja građevnih propisa u NDH, koja je formalno prestala postojati predajom vlastitih vojnih postrojbi 15 . svibnja 1945. na Blajburškom polju Oružanim snagama Ujedinjenoga Kraljevstva Velike Britanije i Sjeverne Irske. ${ }^{62}$

\section{Abrogacija postojećega sustava i mukotrpni počeci stvaranja socijalističkoga građevnog prava između 1945. i 1956. godine}

Dana 12. lipnja 1946. stupio je na snagu savezni Zakon o općedržavnom planu i državnim organima za planiranje, kojim je formalno uvedena planska privreda u jugoslavenski gospodarski sustav. ${ }^{63}$ Tim je zakonom uspostavljena Savezna planska komisija, čiji je predsjednik po položaju bio član Vlade FNRJ, a bile su joj dodijeljene diktatorske ovlasti u vođenju gospodarstva. Analogno saveznoj razini svaka od republika i autonomnih pokrajina imala je vlastitu plansku komisiju, čiji je predsjednik bio član vlade dotične republike odnosno autonomne pokrajine, uključujući NRH. Dana 2. studenog 1946. stupio je na snagu Zakon o nevažnosti pravnih propisa važećih prije 6. 4. 1941. godine $i$ za vrijeme neprijateljske okupacije, kojim je formalno ukinut postojeći pravni sustav, uključujući i građevno zakonodavstvo. ${ }^{64}$ Međutim, do donošenja pojedinoga propisa novoga socijalističkog zakonodavstva stari je ekvivalentni propis mogao ostati na snazi ako nije bio u suprotnosti s novim društvenim sustavom. ${ }^{65} \mathrm{U}$ sustavu građenja očito je dolazilo do ambivalentnih tumačenja,

${ }_{61}$ Za kontinuirano varirajuće odnose između federalizma i centralizma važno je napomenuti da je 7. ožujka 1945. (pravni poredak NDH još postoji) kralj Petar II. Karađorđević prenio ovlasti na Kraljevsko namjesništvo, koje je istoga dana proglasilo Privremenu vladu DFJ (raspuštena proglašenjem FNRJ 29. studenog 1945.): premijer maršal Josip Broz Tito, ministar vanjskih poslova i jedini ban Banovine Hrvatske (1939. - 1943.) Ivan Šubašić (dao ostavku 8. listopada 1945.), ministar građevina dr. Rade Pribičević (7. ožujka - 24. travnja 1945.) odnosno Stevan Zečević (24. travnja - 29. studenog 1945.), ministar za Hrvatsku dr. Pavle Gregorić, kasnije predsjednik Kontrolne komisije NRH (1946. - 1948.). Dana 2. veljače 1946. ministar građevina postaje Vlada Zečević i ostaje na toj dužnosti do ukidanja saveznoga ministarstva građevina i prijenosa ovlasti na republička ministarstva 1950. godine.

62 Time formalno prestaje postojati pravni poredak NDH, to jest na cijelom području nove hrvatske federalne jedinice vrijedi jugoslavenski pravni poredak do odluke o državnom ustrojstvu (kralj Petar II. formalno je vladar, a zakone potpisuje Kraljevsko namjesništvo do 29. studenog 1945.). Taj oblik državnoga ustrojstva zove se Demokratska Federativna Jugoslavija. Može se smatrati da je Federalna Hrvatska, zajedno s pet ostalih federalnih zemalja (Srbija, Slovenija, Crna Gora, Bosna i Hercegovina, Makedonija) u neku ruku baštinik federalne Banovine Hrvatske.

63 „Zakon o općedržavnom planu i državnim organima za planiranje”, SL FNRJ, 45 (1946), 517.

${ }^{64}$ Prilog: B. (4) (SL FNRJ, 86/1946). Dalje će zbog ekonomičnosti taksativno navedeni građevni zakoni i propisi biti citirani na taj način.

${ }^{65}$ Godine 1945. Službeni list DFJ naizmjenično je izlazio na srpskom (ćirilica), hrvatskom (latinica), slovenskom (latinica) i makedonskom jeziku (ćirilica), a u poslovnicima obaju domova konstituante taksativno je određeno da novi jugoslavenski Ustav bude napisan na četiri državna jezika (srpski, hrvatski, slovenski, makedonski). Nažalost, 1946. novi Ustav napisan je 
koja su formalno razriješena službenim Objašnjenjem Ministarstva građevina od 26. svibnja 1948. godine. ${ }^{66}$ Dana 6. prosinca 1946. objavljen je Zakon o nacionalizaciji privatnih privrednih poduzeća, kojim su uz ostalo podržavljene sve građevinske tvrtke i samostalni projektni uredi. ${ }^{67}$ Ministarstvo građevina NRH ukinulo je 22. veljače 1946. inženjerske komore u Zagrebu i Splitu. ${ }^{68}$

Saveznim ministarstvom građevina neformalno je rukovodio pomoćnik ministra, hrvatski kadar, arhitekt Branko Tučkorić. ${ }^{69}$ Prioritetni građevni zadaci bili su izgradnja Novoga Beograda započeta gradnjom Palače Predsjedništva Vlade FNRJ ${ }^{70}$, odnosno izgradnja tzv. Autoputa Beograd - Zagreb kao simbola povezanosti glavnih gradova dvaju najvećih jugoslavenskih naroda. Da bi se to osiguralo, bilo je potrebno centralizirati građevinsku djelatnost i urediti plansku privredu. Branko Tučkorić pokrenuo je 1947. izdavanje biltena saveznoga ministarstva građevina Naše građevinarstvo, u kojem su objavljivani podzakonski propisi sve do ukidanja toga ministarstva 1950. godine. ${ }^{71}$ Tako postavljeni prioriteti u obnovi i izgradnji savezne države i republike Hrvatske zahtijevali su plansku koordinaciju građevne struke. Saveznim zakonom već su 1946. nacionalizirana sva građevna i projektna poduzeća. Osnovane su savezna planska komisija i njoj podređene republičke planske komisije, bez čijega pozitivnog mišljenja nije bilo moguće započeti nikakvu građevnu djelatnost. Projektanti s hrvatskoga područja bili su kolektivizirani u Zemaljski građevno-projektni zavod NRH, kojim je upravljao provjereni kadar, inženjer arhitekture Branko Tučkorić, a nakon njegova odlaska u Beograd arhitekt Veljko Kauzlarić. Obojici je pomagao predratni povjerenik za inženjerske komore Banovine Hrvatske arhitekt Vladimir Potočnjak, koji je poslije sa Zlatkom Neumannom osvojio prvu nagradu i izvedbu na natječaju za Palaču Predsjedništva Vlade FNRJ. ${ }^{72}$ Njihov treći partner na istom natječaju, arhitekt Antun Ulrich, preuzeo je estetsko oblikovanje Autoputa Beograd - Zagreb, koje je prema navedenim referencama bilo zamišljeno potpuno u

na hrvatsko-srpskom jeziku (latinicom s otprilike $2 / 3$ do $3 / 4$ hrvatske terminologije, a suprotni terminološki standard definiram kao srpsko-hrvatski, kad se piše latinicom, odnosno српскохрватски kad se piše ćirilicom). Dalje u članku i Prilogu sve pravne propise donosim prema hrvatsko-srpskom jezičnom standardu. Valja reći da već 1921. Državni almanah Kraljevstva Srba, Hrvata i Slovenaca državni jezik u engleskom prijevodu definira kao Croatoserbian.

66 Prilog: B. (5) (26. 5. 1948., Naše građevinarstvo, II, srpanj 1948.)

67 „Zakon o nacionalizaciji privatnih privrednih poduzeća”, SL FNRJ, 98 (1946), 1245.

68 Prilog: B. (6) (NN NRH, 33/1946).

69 Nažalost, nije bio moguć uvid u akte kojima je Branko Tučkorić bio postavljen za pomoćnika saveznoga ministra građevina Vlade Zečevića, odnosno razriješen rukovodeće dužnosti u Zemaljskom građevno-projektnom zavodu NRH.

70 Danas „Palata Srbija”.

71 Početkom 1952. u prvom broju časopisa Naše građevinarstvo, sada biltena Saveznoga komiteta za građevinarstvo, objavljeni su komentari novih građevnih propisa pod utjecajem novoga privrednog sustava, kako se neslužbeno zvalo labavljenje centralizma pod utjecajem novih jugoslavenskih saveznika SAD-a, NATO-a, odnosno Grčke i Turske (Balkanski pakt).

72 KAHLE, „Architect Zlatko Neumann: Works after the Second World War (1945-1963)”, 174-176. 
duhu Reichsautobahnena Njemačkoga Reicha. ${ }^{73}$ Može se tvrditi da je taj kadrovski sastav utjecao na pisanje saveznih zakona i propisa sve do ukidanja saveznoga ministarstva građevina 1950. godine. Jedan od glavnih priručnika u tom poslu bio je Bauordnungslehre Ernsta Neuferta objavljen 1944. u Berlinu, koji je u međuvremenu Vladimir Potočnjak, uz neslužbenu pomoć Zlatka Neumanna, 1952. preveo na srpsko-hrvatski jezik pod naslovom Pravila građevinarstva. Od tehničkih propisa donesenih u Tučkorićevo vrijeme treba navesti standardizaciju projektne dokumentacije u njemačkom formatu DIN A4 i njegovim izvedenicama, što je bilo prepisano i prilagođeno iz Neufertova kapitalnoga djela Bauentwurfslehre, dostupnog u Jugoslaviji od 1936. godine.

$\mathrm{Na}$ početku donošenja saveznih građevnih propisa donijeta je 1947. Uredba o privremenim normama i privremenim tehničkim propisima u građevinarstvu, koju je neposredno slijedila Uredba o privremenim tehničkim propisima za beton i armirani beton (PTP-3). Nadalje su 1948. donijeta rješenja o privremenim tehničkim propisima za opće građevno fundiranje i fundiranje na šipovima (PTP-1), za opterećenje zgrada (PTP-2), 1949. za oznake iz građevinske mehanike (PTP-4), za opterećenje mostova na putovima (PTP-5), o načinu obrade idejnoga projekta za visokogradnje faza B1 i B2 (PTP-6), za zidove od opeke (PTP-7), za drvene konstrukcije (PTP-8), za tipizaciju građevinskih bitumena (PTP-9), a 1950. o načinu obrade idejnoga projekta za visokogradnje faza B3 i B4 (PTP-6a). Javno-pravni odnosi između sudionika u izgradnji propisani su 1948. osnovnim uredbama o građenju ${ }^{74}$, građevinskoj inspekciji ${ }^{75}$ i projektiranju ${ }^{76}$, kojima su u pravnu proceduru izdavanja odobrenja za građenje odnosno za upotrebu uvedeni društveno planiranje, odnosno društvena kontrola. Uspostavom utjecaja uvjetnoga procesa društvenoga planiranja na nužni proces građevno-pravne procedure Partija je kontrolirala kompletnu građevnu djelatnost na saveznoj razini, uključujući republičke i pokrajinske razine. Godine 1949. donijeta je Osnovna uredba o generalnom urbanističkom planu ${ }^{77}$, kojom je postojeći sustav gradogradnje temeljen na Generalnom regulacionom planu i Građevinskom pravilniku zamijenjen labavijim sustavom generalnih i provedbenih urbanističkih planova. ${ }^{78}$ Novo rješenje bilo je neosporno slabiji pravni instrument jer su uskoro provedbene osnove, odnosno provedbeni urbanistički planovi počeli simulirali građevinske pravilnike (redove građenja) za pojedina naselja odnosno gradove. ${ }^{79}$ Predratni propisi za

73 ULRICH, „Trasiranje cesta za brzi promet”, 130-145.

74 Prilog: C. (13) Osnovna uredba o građenju (SL FNRJ, 46/1948), Uredba o građenju (SL FNRJ, 14/1952).

75 Prilog: C. (14) (SL FNRJ, 46/1948, 12/1952).

76 Prilog: C. (15) Osnovna uredba o projektiranju (SL FNRJ, 48/1948), Uredba o građevinskom projektiranju (SL FNRJ, 12/1952).

77 Prilog: C. (25) (SL FNRJ, 78/1949).

78 TANDARIĆ, WATKINS, IVES, „Urban planning in socialist Croatia / Urbano planiranje u Hrvatskoj tijekom socijalističkoga režima", 5-41.

79 BENCETIĆ, „Zagrebačka stanogradnja u prijedlozima planova i generalnim urbanističkim planovima od 1945. do 1990.", 389-418. 
beton i armirani beton od 6. studenog $1935 .^{80}$ zamijenjeni su jednostavnijim, ali lošijim rješenjem, koje je propisivalo veću upotrebu betona u odnosu na armaturu jer je čelik bio dragocjen materijal. O tome svjedoče na primjer predimenzionirani stupovi zapadne tribine stadiona „Dinama”, koje je oblikovao arhitekt Vladimir Turina prema statičkom računu inženjera konstruktora Eugena Erliha. ${ }^{81}$ Zaključno, prvi jugoslavenski propisi za projektiranje čeličnih konstrukcija doneseni su tek sredinom 1960-ih.

Rezolucija Informbiroa na Vidovdan 1948. ostavila je Jugoslaviju bez sovjetske ekonomske pomoći i okrenula Ujedinjenom Kraljevstvu, Sjedinjenim Američkim Državama i Zapadnoj Njemačkoj. Na zakonodavnoj razini to se očitovalo u labavljenju centralističkoga gospodarskog sustava i uvođenju samoupravljanja kao specifičnoga jugoslavenskog puta u socijalističko društvo. Takva promjena nije mogla biti izvedena u tjednima ili mjesecima, nego je trajala barem nekoliko godina. Tako je Naše građevinarstvo još godinu i pol, sve do početka 1950., objavljivalo reportaže iz „bratskoga” Sovjetskog Saveza i ostalih država komunističkoga lagera. U proljeće 1950. glavni urednik Našega građevinarstva postaje slovenski kadar, arhitekt Janez Valentinčič, jedan od Plečnikovih učenika, i uskoro časopis objavljuje reklame američkih, britanskih i zapadnonjemačkih građevnih strojeva. Jedna od hrvatskih posebnosti toga preokreta bilo je osnivanje privatnih arhitektonskih projektnih ureda: najprije 1952. nastaju Ostrogović i Haberle, a početkom 1954., raspadom Arhitektonskoga projektnog zavoda, nasljednika Zemaljskoga građevno-projektnog zavoda NRH, nastalo je 12 arhitektonskih ureda, među njima Loewy, Neumann, Pavešić, Auer i Delenardo. Vlastiti ured Tučkorić dobio je čak i bivši pomoćnik saveznoga ministra građevina, koji se nakon odlaska iz Beograda zaposlio u bivšem poduzeću, a kao direktor vlastitoga biroa bavio se jugoslavenskom inačicom stanova za Egzistenzminimum, poznatijih kao Tučkorić-stanovi. ${ }^{82}$ Vladimir Potočnjak nažalost nije dočekao vlastiti biro jer je umro 1952. godine. Naravno da direktor takva biroa nije bio njegov vlasnik, nego samo „inokosni poslovodni organ”, koji je za sve važnije odluke morao sazivati radnički savjet, u kojem su i predstavnici čistačica mogli odlučivati o bilo kojem postavljenom pitanju. ${ }^{83} \mathrm{Ti}$ su biroi svi izumrli prirodnom selekcijom, to jest odlaskom u mirovinu njihovih direktora, jer nisu smjeli biti ostavljeni nadarenome nasljedniku kao u zapadnim uzorima, a novi biroi nisu se osnivali, čime su bili uskraćeni daroviti projektanti novije generacije poput Slavka Jelineka, Julija De Luce ili Ante Čičin-Šaina. Tako su 1952. donesene nove osnovne uredbe o građenju i građevinskom projektiranju, kojima je ukinuta revizija projekata, gospodarskim subjektima dana relativna

80 To jest prevedeni švicarski savezni propisi za armirani beton od 14. svibnja 1935.

81 KAHLE, „Rasprava 'Djelovanje potresa na zgrade' akademika Andrije Mohorovičića iz 1911. godine i protupotresna analiza građevnih propisa grada Zagreba u razdoblju od 1857. do 1964. godine", 37.

82 KAHLE, „Architect Zlatko Neumann: Works after the Second World War (1945-1963)”, 178.

83 Pokojni arhitekt Emil Pernar, usmeno priopćenje autoru u neformalnom razgovoru 2007. neposredno nakon obrane autorove doktorske disertacije. 
sloboda u poslovanju, a koordinatori državne kontrole nad tako postavljenim sustavom bile su banke ${ }^{84}$, koje su kontrolirale izradu investicijskih programa odnosno kolaudaciju sagrađenih zgrada ili građevina. ${ }^{85}$ Kako je Partija htjela na još jedan način međusobno kontrolirati odgovorne stručnjake u projektiranju i gradnji, a osim toga nije bilo stručnih ispita još od kraja Drugoga svjetskog rata, 1954. i 1955. doneseni su pravilnici o stručnom ispitu za odgovorne stručnjake građevne struke, gdje uopće nisu bili spomenuti arhitekti, nego su odgovorni stručnjaci bili podijeljeni u dvije skupine: odgovorni građevinski projektanti i odgovorni rukovodioci gradilišta - podjela koja nije postojala ni u jednoj strukovnoj komori zapadne provenijencije. Arhitekti su osobnim primanjem kod predsjednika FNRJ maršala Josipa Broza Tita uzalud pokušali promijeniti pravilnik u vlastitu korist. Zaključno, sustav propisa vezanih za graditeljstvo postao je jako složen, što je najvjerojatniji uzrok objave repetitorija građevnih propisa i procedura NRH 1956. godine.

Analiza građevnih propisa na području Narodne, od 1963. Socijalističke Republike Hrvatske između 1956. i 1971. godine

Ing. arh. Vladimir Šilhard (Schilhard) objavio je 1956. repetitorij postojećih građevnih propisa ${ }^{86}$, koji je redaktorski podijelio prema tijeku procesa izrade projektne dokumentacije te izvedbe same zgrade odnosno građevine. Prvo poglavlje odnosi se na izradu investicijskoga programa (A.) u dvije faze: sama izrada investicijskoga programa (A.I.) te njegova revizija od strane nadležnoga organa (A.II.). Drugo poglavlje odnosi se na projektiranje (B.) u dvije faze: sama izrada projekta (B.I.) te revizija projekta od strane nadležnoga organa (B.II.). Treće poglavlje odnosi se na samu izgradnju (C.) u dvije faze: javno nadmetanje (C.I.) te sama izgradnja (C.II.), nakon čega slijedi tehnički pregled (D.) te kolaudacija i superkolaudacija (E.), praktična primjena propisa (F.) te na kraju ispiti i ovlaštenja (G.). Analiza objavljena u repetitoriju pokazuje složenost odnosa među sudionicima projektiranja i izgradnje u „javnom” postupku, zbog čega je proces projektiranja i same gradnje trajao razmjerno duže nego u sumjerljivim zemljama Zapadne Europe. Godina u kojoj je Šilhard objavio repetitorij građevnih propisa bila je važna iz političkoga razloga. Naime, u Sovjetskom Savezu je Nikita Hruščov na 20. kongresu Komunističke partije Sovjetskoga Saveza (boljševika) razotkrio Staljinov kult ličnosti članstvu sovjetske partije. Sljedeći njegov korak bio je sastanak s Josipom Brozom Titom, gdje je jugoslavenski predsjednik potvrdio svoju privrženost socijalističkom društvenom sustavu, a Jugoslavija je vanjskopolitički odlučila olabaviti savezništvo sa zapadnim silama i krenula tzv. nesvrstanim putem. Uskoro su sažeci na ruskom jeziku vraćeni u sve stručne graditeljske i

84 BOJIĆ, „Odnos između građevinskog preduzeća i banke”, 53.

${ }^{85}$ KALAFATOVIĆ, „Odnos: Investitor - izvođačko preduzeće”, 58.

86 ŠILHARD, „Repetitorij građevnih propisa i procedure u N. R. Hrvatskoj”, 9-10. 
arhitektonske časopise (Arhitektura, Čovjek i prostor, Građevinar). U Beogradu je 1960. pokrenuto izdavanje časopisa Arhitektura, urbanizam, čime je de facto bila završena svejugoslavenska uloga zagrebačkih arhitektonskih časopisa Arhitektura odnosno Čovjek i prostor te ljubljanskoga časopisa Arhitekt.

Godine 1958. donesen je jugoslavenski savezni zakon o nacionalizaciji stambenih zgrada za iznajmljivanje, pri čemu su bivši vlasnici smjeli zadržati jedan, a najviše dva stana u vlasništvu. Uvedeni su kućni savjeti kao organi upravljanja svake pojedine zgrade, ali je taj eksperiment samo povećao pravnu zbrku stvarnih, odnosno legalnih prava, što se može tumačiti sukcesivnim donošenjem, popravcima odnosno ukidanjem hrpe saveznih zakona o „općim” stambenim odnosima ${ }^{87}$ te gradnji i gospodarenju „društvenim” stambenim zgradama. ${ }^{88}$ Iste godine u NRH donesen je Zakon o nadogradnji zgrada, koji ocrtava sliku o kroničnom nedostatku stambenoga prostora u većim hrvatskim gradovima, osobito u Zagrebu. Njegova posljedica bilo je podizanje prosječne katnosti u većini blokova zagrebačkoga Donjega grada za jedan, a nerijetko i dva kata. Kako su uime pojedinih stambenih zgrada predviđenih za nadogradnju nastupali njihovi kućni savjeti, to je samo povećalo zbrku u projektiranju i realizaciji takva načina smanjenja nestašice stambenoga prostora. Donesen prije potresa u Skopju $1963 .^{89}$, taj zakon nije propisao protupotresnu analizu utjecaja nadogradnje na stabilnost izvorne građevine, pa se može tvrditi da su to većinom najranjivije građevine nakon recentnih potresa 2020. godine. Ono što se u građevnoj regulativi toga vremena ne vidi, a upotpunjuje sliku nedostatka stambenoga prostora, jest prešutna tolerancija nelegalne izgradnje malih, uglavnom obiteljskih stambenih zgrada, posebno $u$ blizini većih industrijskih pogona, na primjer naselja Kozari bok i Kozari put na Žitnjaku. Krajem 1960-ih, odnosno početkom 1970-ih odlučeno je da se legaliziraju sve nelegalno podignute stambene zgrade vidljive na aerofotogrametrijskoj snimci državnoga teritorija od 15. veljače 1968. godine.

U tehničkom pogledu svi propisi, pravilnici i standardi bili su donošeni na saveznoj razini, čime se bavio Savezni zavod za standardizaciju u sastavu Saveznoga sekretarijata za industriju, poslije Saveznoga sekretarijata za privredu. Početkom 1960-ih započelo je donošenje tehničkih pravilnika koji su regulirali projektiranje i izvedbu konstrukcije građevnih objekata. Jedan od prvih propisa bio je Pravilnik o privremenim tehničkim propisima za građenje u seizmičkim područjima iz $1964 . .^{90}$, donesen kao posljedica katastrofalnoga

87 U časopisu Čovjek i prostor iz studenoga 1981., posvećenom prikazu stanja stanovanja i stanogradnje u SRH, tada već poznati karikaturist, a po zvanju arhitekt, Joško Marušić objavio je na stranici 46 karikaturu na kojoj je nacrtao knjigu Rimsko pravo normalne debljine, a nasuprot knjigu Stanarsko pravo - dio prvi korica istih dimenzija, ali debljine dva i pol puta veće od širine, to jest knjigu otprilike sedam puta deblju od Rimskoga prava.

88 MRČELA, „Neki aspekti odnosa ponuda i potražnje u stanogradnji Jugoslavije od 1945. do danas", 13.

89 KAHLE, „Rasprava 'Djelovanje potresa na zgrade' akademika Andrije Mohorovičića iz 1911. godine i protupotresna analiza građevnih propisa grada Zagreba u razdoblju od 1857. do 1964. godine", 29.

90 B. FURUNDŽIĆ, S. FURUNDŽIĆ, Zbirka tehničkih propisa, knj. 1, 31-48, tumačenje 52-97. 
potresa u Skopju 1963. godine. Taj pravilnik donio je prvu seizmičku državnu kartu s potresnim zonama od VI. do IX. zone prema Mercalli-Cancani-Siebergovoj ljestvici (slika 1), koja je potjecala iz 1950. (zato nije bila označena državna granica Jugoslavije s Italijom ispod Bovca jer je formalno postojao Slobodni Teritorij Trsta), a posljedično je bilo određeno da za svaku pojedinu građevinu projektant konstrukcije treba tražiti precizne podatke od lokalnoga seizmološkog ureda. U tehničkom pogledu taj je pravilnik uveo dinamički proračun te se može smatrati da građevine proračunate nakon njegova stupanja na snagu imaju bitno veću seizmičku čvrstoću nego prije, a strukture koje su se nalazile u gradnji bile su naknadno seizmički ojačane, poput čuvenih nebodera Rakete na Vrbiku arhitekta Vjenceslava Richtera i suradnika. Šezdesetih je godina pri donošenju zbirke propisa za konstruiranje, proračun, montažu i održavanje čeličnih konstrukcija bila uvedena karta kojom je državni teritorij podijeljen na tri zone s obzirom na djelovanje vjetra (slika 2).

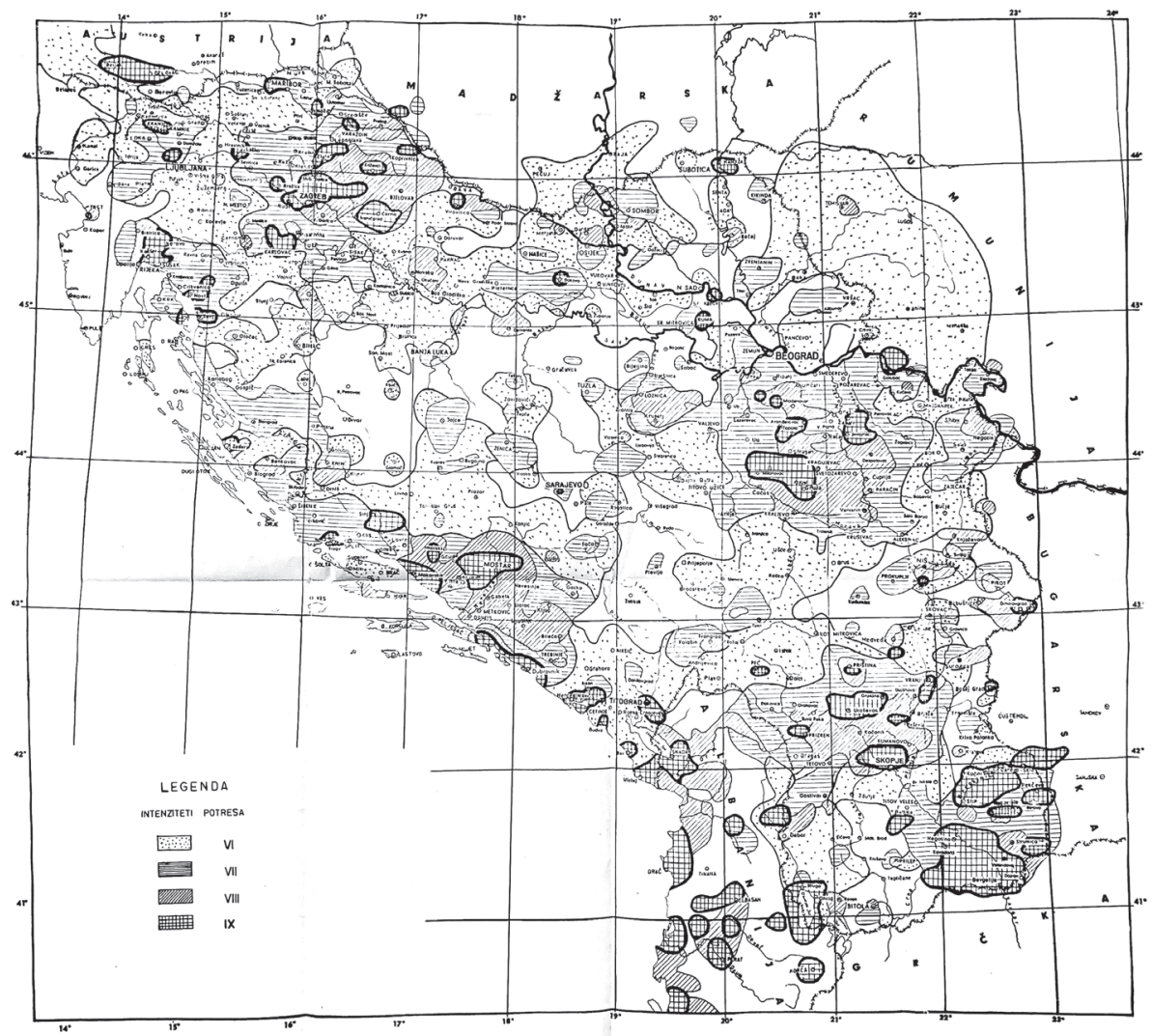

Slika 1. Seizmološka karta FNRJ iz 1950., prilog Pravilniku o privremenim tehničkim propisima za građenje u seizmičkim područjima (1964.). Izvor: B. FURUNDŽIĆ, S. FURUNDŽIĆ, Zbirka tehničkih propisa, knj. 1, 48-49. 


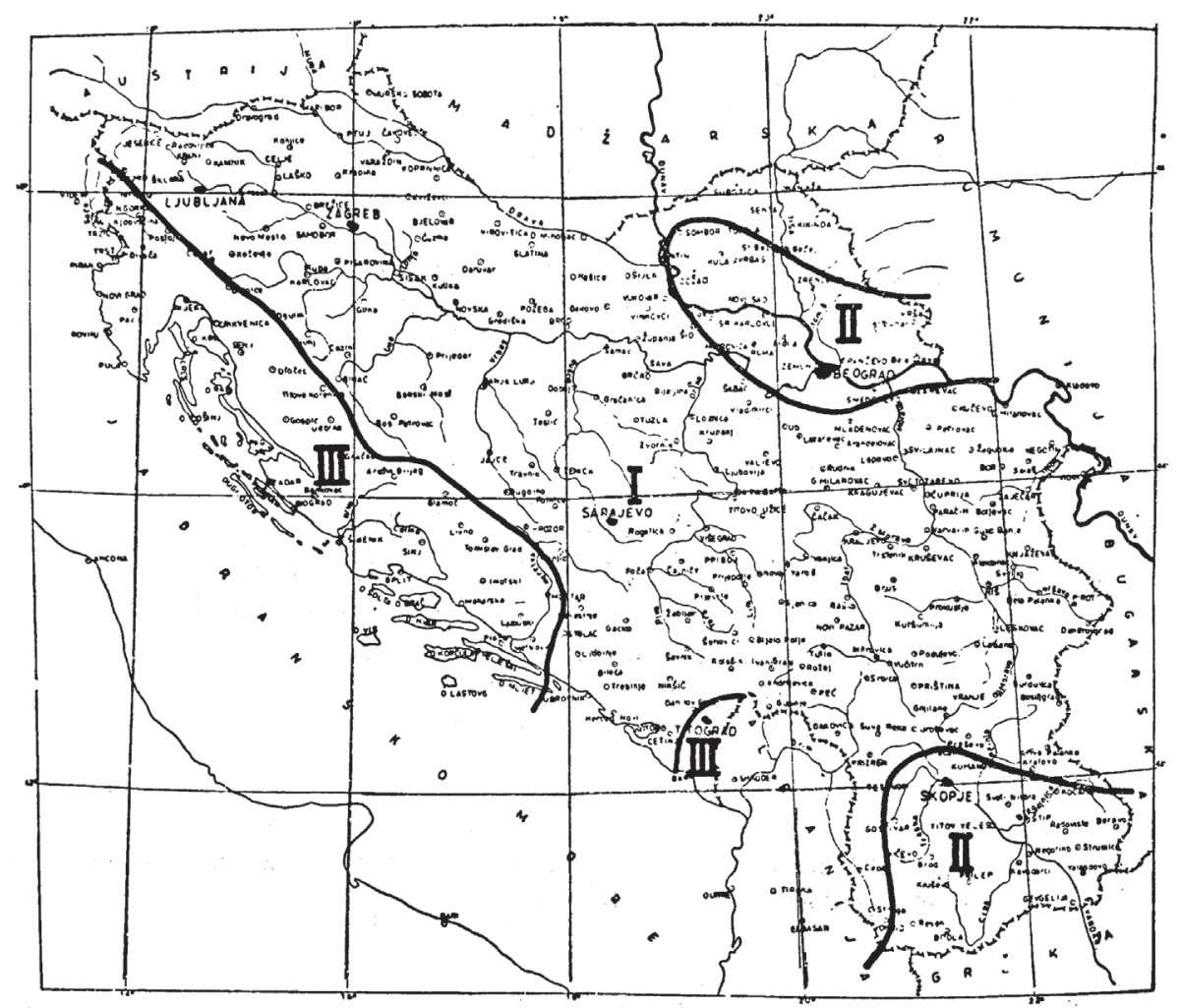

Slika 2. Podjela teritorija Jugoslavije na geografske zone brzine vjetra, prilog Pravilniku o tehničkim propisima o djelovanju vjetra na noseće čelične konstrukcije (1964.). Izvor: B. FURUNDŽIĆ, S. FURUNDŽIĆ, Zbirka tehničkih propisa, knj. 1, 596.

Krajem 60-ih godina doneseni su i preostali tehnički propisi: 1967. Pravilnik o minimalnim tehničkim uvjetima za izgradnju stanova, a 1970. i Pravilnik o tehničkim mjerama i uvjetima za toplotnu energiju u zgradama, koji je propisivao proračun gubitka toplinske energije kroz ovojnicu, čime se može smatrati dalekom pretečom današnjega sustava proračuna i certifikacije energetskih svojstava zgrade. On je sadržavao Kartu građevno klimatskih zona SFRJ (slika 3). 


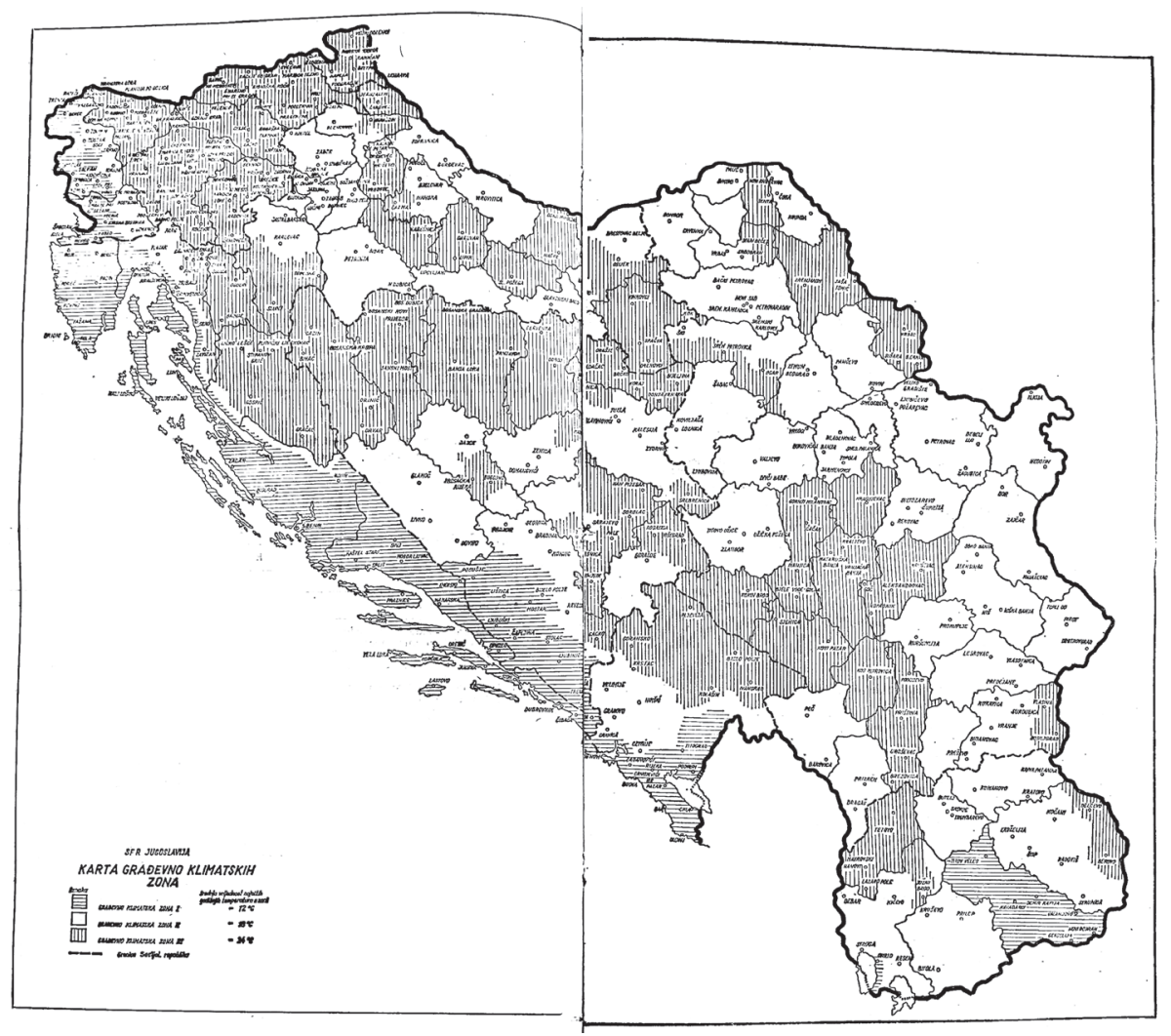

Slika 3. Klimatološka karta SFRJ iz 1970, prilog Pravilniku o tehničkim mjerama $i$ uvjetima za toplotnu zaštitu zgrada. Izvor: „Pravilnik o tehničkim mjerama i uvjetima za toplotnu zaštitu zgrada”, SL SFRJ, 35 (1970), 1000-1001.

Krajem 50-ih godina politički konsenzus u okviru savezne i republičkih komunističkih partija, kao protuteža zbližavanju sa Sovjetskim Savezom i Varšavskim paktom, omogućio je daljnju decentralizaciju građevne regulative. Početkom 60 -ih godina urbanizam, gradogradnja i prostorno planiranje bili su potpuno prepušteni republikama te je na saveznoj razini formalno ukinuta Osnovna uredba o GUP-u, a u Hrvatskoj je 1961. donesen Zakon o urbanističkom i regionalnom prostornom planiranju. Iste godine na saveznoj razini donesen je Osnovni zakon o izgradnji investicionih objekata, koji je propisivao okvire koordinacije izgradnje na saveznoj razini, odnosno između republika (čime su osnovne uredbe otišle u povijest). U Hrvatskoj je sljedeće godine donesen Zakon o izgradnji investicionih objekata, a poslije i zakoni o građevinskoj inspekciji, odnosno o građenju objekata građana i građanskih pravnih osoba. Na taj način htjelo se dodatno stigmatizirati privatne investitore jer su pod građanske pravne osobe spadale tzv. vjerske organizacije, među njima Katolička crkva, Srpska pravoslavna crkva, Mešihat Islamske zajednice itd. Arhitekti i inženjeri koji su se bavili projektiranjem i izvođenjem takvih 
objekata bili su izdvojeni u posebnu grupu, čiji članovi nisu smjeli formalno sudjelovati u projektiranju i nadzoru „društvenih” investicijskih objekata čak ni kao tzv. vanjski suradnici, čime se htjelo odvratiti ambiciozne arhitekte od projektiranja „kureka”, kako su pogrdno nazivani tzv. individualni stambeni objekti građanskih osoba. Postoji određeni broj takvih obiteljskih zgrada odnosno vila koje su projektirali poznati arhitekti, ali potpisali anonimni projektanti. Krajem 60-ih godina, kao odgovor na utjecaj Hrvatskoga proljeća, odnosno pod dojmom okupacije Čehoslovačke od strane Crvene armije i nekih članica Varšavskoga ugovora 1968., predsjednik SFRJ Josip Broz Tito odlučio je dodatno militarizirati društvo uvođenjem sustava tzv. općenarodne obrane i naoružanoga naroda, najvjerojatnije po uzoru na Švicarsku Konfederaciju, te je posljedično tome bio organiziran odgovarajući pravni okvir, u koji su napose spadali zakoni i pravilnici o izgradnji atomskih skloništa, koja su bila intenzivno građena kasnije, od 1971. do 1990. godine. ${ }^{91}$ Jugoslavenska narodna armija bila je izdvojena u svim pitanjima građevne regulative vezano za vojne objekte, a njezini su predstavnici imali utjecaja na planiranje i projektiranje svih građevina za koje bi bio ocijenjen vojno-strateški značaj.

\section{Diskusija i zaključak}

Zemlje i područja koja čine današnje hrvatsko državno područje zatekli su se nakon završetka Bečkoga kongresa 1815. u sastavu Austrijske Carevine, odnosno zajedničke države prvi put poslije podjele Rimskoga Carstva 395. i propasti Zapadnorimskoga Carstva 476. godine. Sve te povijesne jurisdikcije imale su u vrijeme Bečkoga kongresa 1814./1815. naslijeđene sustave građevnih propisa iz srednjega vijeka, to jest gradovi jadranskoga dijela Hrvatske imali su vlastiti gradski statut sa odgovarajuće detaljnim građevnim propisima po uzoru na talijanske gradove-republike, a gradovi kontinentalnoga dijela Hrvatske imali su vladarske povelje s manje ili više uopćenim odredbama o građenju po uzoru na slične srednjoeuropske monarhije. U Austrijskoj Carevini današnje hrvatsko državno područje pripadalo je različitim jurisdikcijama, odnosno kraljevinama Hrvatskoj i Slavoniji s Vojnom krajinom, Kraljevini Dalmaciji uspostavljenoj 1815., Kraljevini Iliriji u razdoblju 1816. - 1849., a poslije Priobalju, nadalje Ugarskom Kraljevstvu i Njemačkom Savezu. Već prije propasti revolucije 1848. austrijski ministar predsjednik princ Schwarzenberg krenuo je u centralizaciju Austrijske Carevine, kojom su sve povijesne zemlje nivelirane u status krunovine, ukinuto je kmetstvo, zajamčene su osobne slobode, uključujući slobodu vlastitoga jezika, započela je centralizacija uprave i zakonodavstva, a carevinsko službeno državno glasilo izlazilo je osim na njemačkom na još osam službenih jezika, pa i hrvatskom sve do kraja 1852. godine. Početak stvaranja austrijskoga, a time i hrvatskoga građanskog sustava građevne regulative predstavlja napredni Propis o prijemu

91 KAHLE, „Fallout Shelters in Zagreb After the End of World War II”. 
graditeljskih pitomaca i uvođenju državnih ispita u graditeljstvu iz 1850., kojim je bila propisana izobrazba stručnjaka tehničkih struka na onodobnim tehničkim visokim školama. Nakon Schwarzenbergove smrti 1852. taj je proces zaustavljen, a poslije propasti Bachova apsolutizma 1860. Austrijsko Carstvo pretvoreno je nagodbom 1867. u personalnu, vanjskopolitičku, monetarnu i vojnu uniju dviju samostalnih država, Cislajtanije (to jest zemalja zastupljenih u Carevinskom vijeću) i Translajtanije (to jest zemalja krune sv. Stjepana, gdje je međusobni odnos Ugarske i Hrvatske bio određen nagodbom iz 1868.). Drugim riječima, poslije 1868. postojala su tri različita djelomično decentralizirana sustava građevnoga prava na dijelovima teritorija Hrvatske, i to hrvatski (Hrvatska i Slavonija, kasnije Vojna krajina), austrijski (Dalmacija s Dubrovnikom i Istra) i mađarski (Rijeka, Međimurje i Baranja). U hrvatskom sustavu građevnoga prava Zagreb je dobio građevni red već 1857., okolica Plitvičkih jezera 1899., a preostali gradovi i sela 1900. godine. Ustrojstvo civilnih inženjera i arhitekata propisano je 1877., a položaj uređen 1911. na neformalnom komorskom principu. U austrijskom sustavu građevnoga prava civilni inženjeri i arhitekti bili su u Istri priznati već 1861., a građevni red propisan 1874. godine. Za Dalmaciju je građevni red propisan 1886. godine. Propašću Habsburške Monarhije i stvaranjem prve jugoslavenske države 1918. započela je sljedeća centralizacija građevnih propisa, dovršena donošenjem Građevinskoga zakona iz 1931., odnosno Zakona o ovlaštenim inženjerima i arhitekti$m a$ iz 1937. godine. Važni podzakonski akti bili su Pravilnik za uređenje sela $i$ drugih naselja u Savskoj banovini iz 1938. (nije se protezao na Dalmaciju), Gradevinski pravilnik za grad Zagreb iz 1940., odnosno prevedeni Švicarski propisi za armirani beton od 14. 5. 1935. godine, odobreni odlukom jugoslavenskoga ministra građevina 16. studenog 1935. godine. Može se tvrditi da su u kraljevskoj jugoslavenskoj centralizaciji građevnih propisa prevladali interesi naprednijih, zapadnih dijelova države. Tako se na primjer u prijelaznim odredbama Zakona o ovlaštenim inženjerima ne spominju prethodni relevantni propisi Kraljevine Srbije, iz čega bi se dalo zaključiti da u tom dijelu zajedničke države nije uopće bila regulirana privatna inženjerska praksa sve do donošenja Privremene uredbe o ovlaštenim inženjerima i arhitektima 1924. godine. Nadalje, strani stručnjaci južnoslavenskoga podrijetla poput direktora švicarskoga EMPA instituta Mirka Roša usrdno su i intenzivno pomagali $\mathrm{u}$ donošenju suvremenih tehničkih propisa koji su bili prevedeni i prihvaćeni, poput današnjih EUROCODE propisa za izračun građevnih konstrukcija.

Za građanski sustav građevnih propisa, formalno ukinut 1946., bila su važna dva zakona: Građevinski zakon iz 1931. i Zakon o ovlaštenim inženjeri$m a$ iz 1937. godine. U sadašnjem sustavu građevnih propisa postoje razdvojeni Zakon o gradnji (NN RH, 153/2013) i Zakon o prostornom uređenju (NN RH, 153/2013), kao i Zakon o komori arhitekata i komorama inženjera u graditeljstvu i prostornom uređenju (NN RH, 78/2015). Nadalje, postoje dva sustava propisa preuzeta ulaskom Republike Hrvatske u Europsku uniju 2013., i to za projektiranje konstrukcije EUROCODE te sustav zakona i propisa za projektiranje i certificiranje potrošnje energije. Nažalost, Generalni urbanistički plan 
grada Zagreba koji je na snazi, popularno poznat kao GUP, sastavljen je od zbirke „Zakrpa” prikupljanih još od Osnovne uredbe o GUP-u iz 1949. i neprihvaćene Direktivne regulatorne osnove grada Zagreba iz 1953. godine. Drugim riječima, recentni sustav građevnih propisa samo je nastavak socijalističkoga sustava građevne regulative započetog 1946., temeljenog na Osnovnoj uredbi o građenju iz 1948. te Osnovnoj uredbi o generalnom urbanističkom planu iz 1949., a preuzeti su propisi koji su bili posljedica ulaska Republike Hrvatske u Europsku uniju. Taj socijalistički sustav građevne regulative utemeljen 1947. bio je uglavnom dovršen krajem 1971., iako su neki važniji propisi kasnije bili osuvremenjeni (npr. novi savezni pravilnici za izračun protupotresnih konstrukcija 1981., odnosno za beton i armirani beton 1987.). Za socijalistički sustav građevne regulative karakteristična je podvojenost zakonskih rješenja tamo gdje je prije postojalo jedinstveno zakonsko rješenje (osnovne uredbe iz 1948. odnosno 1949. zamjenjuje jedinstveni zakon iz 1931.), kao i konstantne promjene, ispravci i konsekutivna donošenja takozvanih pročišćenih tekstova više puta ispravljanih uredbi odnosno zakona u ovisnosti o nepredvidivim skretanjima savezne državne politike: 1948. prekid sa Sovjetskim Savezom i neformalno članstvo u zapadnim asocijacijama, uključujući vojnu pomoć, 1958. približavanje Sovjetskom Savezu nakon Hruščovljeva referata na 20. kongresu Komunističke partije Sovjetskoga Saveza 1956., uz nesvrstanu vanjsku politiku i kupovinu sovjetskih nadzvučnih lovačkih zrakoplova, zatim 1969. teorija „naoružanoga naroda” kao odgovor na okupaciju Čehoslovačke 1968., koja će 1971. biti proklamirana ustavnim amandmanima, a 1974. verificirana novim Ustavom SFRJ. Te postavke mogu se plastično modelirati na primjeru ambivalentnosti savezne (posljedično i republičke hrvatske) politike prema položaju arhitekata u društvu. Narodna Republika Hrvatska ukinula je 1946. inženjerske komore u Zagrebu i Splitu, arhitektonska djelatnost bila je definirana pojmom građevinsko projektiranje, a svi arhitekti i inženjeri kolektivizirani su u Zemaljskom građevno-projektnom zavodu NRH. Podjelom poslova i međuljudskim afinitetima počele su se stvarati projektantske grupe, koje su početkom 50-ih godina dobile imena svojih rukovodilaca (APB Ostrogović, APB Haberle, APB Neumann itd.), pa su se politički rukovodioci mogli hvaliti zapadnim sponzorima da u Jugoslaviji (zapravo samo u Sloveniji i Hrvatskoj) postoje privatni arhitektonski biroi, u kojima je međutim predstavnik neprofesionalnih radnika u radničkom savjetu imao pravo glasa i u potpuno tehničkim pitanjima u kojima je bio stručno nekompetentan. Nakon zbližavanja Tita i Hruščova krajem 50-ih godina ti su biroi pušteni da evolucijski odumru jer nije bilo dopušteno stvaranje novih (arhitekt Julije De Luca bio je šef arhitektonskoga biroa Industrijskoga projektnog zavoda, a arhitekt profesor dr. sc. Nikola Filipović predavao je arhitektonsko projektiranje na Arhitektonskom fakultetu). U 60-im godinama biroi su se pod utjecajem politike polako okrupnjivali, a uvođenjem delegatskoga sustava sredinom 70 -ih godina ponovno su neformalno kolektivizirani u okviru inženjering radnih organizacija (iako je darovitim pojedincima poput arhitekta Edvina Šmita /Schmitt/ uspjelo nametnuti vlastiti autoritet). Čak su i fakulteti koji su se 
bavili projektiranjem odnosno nadzorom morali osnovati vlastite zavode za projektiranje koji su simulirali inženjering organizacije (Zavod za projektiranje Arhitektonskoga fakulteta Sveučilišta u Zagrebu), a u tom je kontekstu svakako najgrotesknije organizacijsko rješenje bio ambivalentan položaj Građevinskoga fakulteta Sveučilišta u Zagrebu kao OOUR-a Građevinskoga instituta u Zagrebu.

Kad se analiziraju pojedina zakonska rješenja građevne regulative socijalističkoga sustava, opet se uočava podvojenost na strogo tehničke propise, gdje se može tvrditi da su bila donošena uglavnom napredna rješenja, iako uz nepotrebno administriranje, i na organizacijske propise poput upravnoga postupka, organizacije građevne službe itd., koji su zapravo bili preslika odnosa u društvu te kao takvi pod manje ili više izravnom kontrolom Partije, odnosno Saveza komunista Jugoslavije/Hrvatske. I ovdje se odražavaju opisana skretanja državne politike, pa tako imamo čvrstu plansku regulativu u razdoblju 1947. - 1951., popuštanje od 1952., a 1958. donesen je savezni zakon o nacionalizaciji najamnih zgrada, vjerojatno da se pokaže „čvrstina puta u socijalizam”. U tom kontekstu upravni je postupak, odnosno odobravanje investicija, ishođenje odobrenja i kontrola gradnje bio neprekidni ekonomski laboratorij, gdje od sredine 60-ih do sredine 70-ih godina postoji čak i simulirana „stambena izgradnja za tržište”. Takvu izgradnju, iako kumulativno nedovoljnu za pokrivanje stambenih potreba stanovništva Hrvatske, pratili su uvjetno rečeno napredni tehnički propisi pod utjecajem zemalja Zapadne Europe doneseni krajem 60-ih godina, na primjer savezni propis o toplinskoj izolaciji zgrada iz 1970. godine. Krajem 60-ih godina donesena je regulativa o izgradnji atomskih skloništa za osnovnu zaštitu stanovništva od ratnih djelovanja, koja su svoju vrijednost dokazala u Domovinskom ratu 1991. - 1995. godine. Time upravo analizirani socijalistički sustav građevnih propisa u svojem tehničkom dijelu može biti ocijenjen uvjetno pozitivno, uza sva ograničenja koja je nametao postojeći socijalistički društveni poredak. 
Prilog. Popis građevnih zakona, uredaba, naredbi, rješenja i pravilnika 1946. - 1971. godine

A. Državni propisi prije 6. travnja 1941. primjenjivani do kraja 1960-ih

(1) Građevinski zakon od 7. VI. 1931. (Službene novine Kraljevine Jugoslavije, br. 133-XLII, 16. 6. 1931., br. 174-LVII, 3. 8. 1931.)

A.1. Banovinski propisi prije 6. travnja 1941. primjenjivani do kraja 1960-ih

(2) Pravilnik za uređenje sela i drugih naselja u Savskoj banovini br. 20931 (Narodne novine: službeni list Savske banovine, 168/1938)

(3) Građevinski pravilnik za grad Zagreb od 10. VII. 1940. (Narodne novine: službeni list Banovine Hrvatske, 292/1940)

B. Savezni propisi o delegitimizaciji propisa prije 6. travnja 1941 .

(4) Zakon o nevažnosti pravnih propisa donesenih prije 6. travnja 1941. i za vrijeme neprijateljske okupacije (SL FNRJ, 86/1946)

(5) Objašnjenje [o pravnim propisima, pravilnicima, normama i standardima važećim dana 6. 4. 1941.] (26. 5. 1948., Naše građevinarstvo II, srpanj 1948.)

B.1. Hrvatski republički propisi o delegitimizaciji propisa prije 6. travnja 1941.

(6) Odluka o obustavi rada inženjerskih komora u Zagrebu i Splitu (NN NRH, 33/1946)

C. Savezne uredbe i rješenja do ukidanja saveznoga ministarstva građevina 1950. godine

(7) Uredba o privremenim normama i privremenim tehničkim propisima u građevinarstvu (SL FNRJ, 32/1947)

(8) Uredba o privremenim tehničkim propisima za beton i armirani beton (SL FNRJ, 46/1947)

(9) Osnovna uredba o građevinskoj struci (SL FNRJ, 64/1947)

(10) Rješenje o privremenim tehničkim propisima za izradu drvenih tavanica manjih raspona (SL FNRJ, 81/1947)

(11) Uredba o obaveznoj izradi kućnih telefonskih razvoda u novogradnjama (SL FNRJ, 83/1947)

(12) Rješenje o privremenim tehničkim propisima za tehničko građevinsko fundiranje i fundiranje na šipovima (SL FNRJ, 42/1948)

(13) Osnovna uredba o građenju (SL FNRJ, 46/1948), Uredba o građenju (SL FNRJ, 14/1952, 5/1954, 53/1956, 30/1958) 
(14) Uredba o građevinskoj inspekciji (SL FNRJ, 46/1948, 12/1952)

(15) Osnovna uredba o projektiranju (SL FNRJ, 48/1948), Uredba o građevinskom projektiranju (SL FNRJ, 12/1952, 6/1954, 30/1958)

(16) Rješenje o privremenim tehničkim propisima za opterećenje zgrada (SL FNRJ, 61/1948)

(17) Naredba o tehničkoj opremi idejnog i glavnog projekta (SL FNRJ, 99/1948)

(18) Naredba o sastavnim dijelovima i nazivima projektnog elaborata za visokogradnje, inženjerske konstrukcije i cestogradnje ( $S L$ FNRJ, 100/1948)

(19) Rješenje o privremenim tehničkim propisima za oznake iz građevinske mehanike (SL FNRJ, 7/1949)

(20) Rješenje o privremenim tehničkim propisima za opterećenje mostova na putevima (SL FNRJ, 43/1949)

(21) Rješenje o privremenim tehničkim propisima o načinu obrade idejnog projekta za visokogradnje faza B1 i B2 (SL FNRJ, ?/1949)

(22) Rješenje o privremenim tehničkim propisima za zidove od opeke (SL FNRJ, ?/1949)

(23) Rješenje o privremenim tehničkim propisima za drvene konstrukcije (SL FNRJ, ?/1949)

(24) Rješenje o privremenim tehničkim propisima za tipizaciju građevinskih bitumena (SL FNRJ, 66/1949)

(25) Osnovna uredba o generalnom urbanističkom planu (SL FNRJ, 78/1949)

(26) Rješenje o privremenim tehničkim propisima o načinu obrade idejnog projekta za visokogradnje faza B3 i B4 (SL FNRJ, 19/1950)

(27) Ukaz o ukidanju Ministarstva građevina i o osnivanju Savjeta za građevinarstvo i građevnu industriju (SL FNRJ, 27/1950)

\section{C.1. Hrvatska republička rješenja i uredbe do ukidanja saveznoga mini- starstva građevina 1950. godine}

(28) Rješenje o nagradama za inženjerske i arhitektonske radove (NN $N R H, 48 / 1946)$

(29) Uredba o osnivanju Zemaljskog građevno projektnog zavoda Narodne Republike Hrvatske (NN NRH, 50/1946)

\section{Savezni zakoni, uredbe i odluke 1950. - 1971.}

(30) Uredba o izradi i odobrenju investicijskog programa i o polaganju depozita za osiguranje isplate investicijskih radova (SL FNRJ, 5/1954, 36/1955, 54/1955, 2/1956, 29/1956, 34/1957) 
(31) Zakon o doprinosu za stambenu izgradnju (SL FNRJ, 57/1955)

(32) Osnovni zakon o zaštiti od požara (SL FNRJ, 18/1956, SL SFRJ, $10 / 1965,25 / 1970)$

(33) Zakon o nacionalizaciji najamnih zgrada i građevinskog zemljišta (SL FNRJ, 52/1958)

(34) Osnovni zakon o izgradnji investicionih objekata (SL FNRJ, 45/1961, SL SFRJ, 5/1965, 52/1966, 10/1967, pročišćeni tekst: SL SFRJ, 20/1967, 30/1968, 55/1969, 60/1970, 24/1971)

(35) Osnovni zakon o zaštiti na radu (SL SFRJ, 15/1965)

(36) Osnovni zakon o privrednom poslovanju i gospodarenju stambenim zgradama u društvenom vlasništvu (SL SFRJ, 35/1965)

(37) Zakon o narodnoj obrani (SL SFRJ, 8/1969)

(38) Odluka o određivanju objekata pri čijoj izgradnji se mora izvršiti prilagođavanje potrebama narodne obrane (SL SFRJ, 5/1970)

\section{D.1. Hrvatski republički zakoni 1950. - 1971.}

(39) Zakon o nadogradnji zgrada (NN NRH, 55/1958, 46/1961, 40/1965)

(40) Zakon o urbanističkom i regionalnom prostornom planiranju (NN NRH, 21/1961, NN SRH, 40/1964, pročišćeni tekst: NN SRH, 46/1964, 39/1966, 18/1969)

(41) Zakon o uvjetima za izgradnju stambenih zgrada i gospodarskih objekata u selu (NN NRH, 45/1961)

(42) Zakon o izgradnji investicionih objekata (NN NRH, 29/1962, NN $S R H, 3 / 1965)$, Zakon o izgradnji investicionih objekata građana i građanskih pravnih osoba (NN SRH, 9/1969, 15/1969, 26/1971)

(43) Zakon o građevinskoj inspekciji (NN SRH, 18/1969)

(44) Zakon o uređenju i davanju na korištenje građevinskog zemljišta (NN SRH, 20/1969)

(45) Zakon o tehničkim uvjetima za ugostiteljske objekte (NNSRH, 29/1970)

\section{E. Savezni pravilnici 1947. - 1971.}

(46) Pravilnik o higijenskim i tehničkim zaštitnim mjerama u građevinarstvu (SL FNRJ, 46/1947), Pravilnik o zaštiti na radu u građevinarstvu (SL SFRJ, ?/1968)

(47) Pravilnik o organizaciji i radu komisije za reviziju idejnih projekata pri Saveznoj planskoj komisiji (SL FNRJ, 98/1948)

(48) Pravilnik o organizaciji i radu komisije za reviziju idejnih projekata pri Ministarstvu građevina FNRJ (SL FNRJ, 98/1948)

(49) Pravilnik o izvođenju gradnja u vlastitoj režiji (SL FNRJ, 112/1948), Pravilnik o izvođenju građevinskih objekata i radova u vlastitoj režiji (SL FNRJ, 32/1957, 54/1957, 19/1961) 
(50) Pravilnik o tehničkim i zdravstveno-tehničkim zaštitnim mjerama pri građenju puteva, mostova i željeznica (SL FNRJ, 80/1949)

(51) Pravilnik o konkursima u oblasti građevinskog projektiranja ( $S L$ FNRJ, 5/1950)

(52) Pravilnik o izdavanju građevinske dozvole (SL FNRJ, 24/1952)

(53) Pravilnik o stručnoj spremi inženjera i tehničara kao odgovornih rukovodilaca za pojedine vrste građevinskih objekata i radova (SL FNRJ, 36/1954)

(54) Pravilnik o ovlaštenim projektantima za građevinsko projektiranje (SL FNRJ, 41/1954)

(55) Pravilnik o općim tehničkim propisima za izradu predmeta i konstrukcija zavarivanjem (SL FNRJ, 19/1959)

(56) Pravilnik o higijensko-tehničkim zaštitnim mjerama pri radu sa dizalicama (SL SFRJ, 29/1964, ?/1969), Pravilnik o mjerama i normativima zaštite pri radu sa dizalicama na kablu (SL SFRJ, 19/1968)

(57) Pravilnik o privremenim tehničkim propisima za građenje u seizmičkim područjima (SL SFRJ, 39/1964)

(58) Pravilnik o tehničkim propisima za ispitivanje, isporuku i primjenu žice za prenapregnuti beton (SL SFRJ, 39/1964)

(59) Pravilnik o općim tehničkim propisima za noseće čelične konstrukcije (SL SFRJ, 41/1964)

(60) Pravilnik o tehničkim propisima za noseće čelične konstrukcije spojene zakovicama i vijcima (SL SFRJ, 41/1964)

(61) Pravilnik o tehničkim propisima za zavarene čelične konstrukcije kod nosećih čeličnih konstrukcija (SL SFRJ, 41/1964)

(62) Pravilnik o tehničkim propisima o kvaliteti zavarenih spojeva za noseće čelične konstrukcije (SL SFRJ, 41/1964)

(63) Pravilnik o tehničkim propisima za ležišta i zglobove kod nosećih čeličnih konstrukcija (SL SFRJ, 41/1964)

(64) Pravilnik o tehničkim propisima za toleranciju mjera i oblika kod nosećih čeličnih konstrukcija (SL SFRJ, 41/1964)

(65) Pravilnik o tehničkim propisima o stabilnosti nosećih čeličnih konstrukcija (SL SFRJ, 41/1964)

(66) Pravilnik o tehničkim propisima o djelovanju vjetra na noseće čelične konstrukcije (SL SFRJ, 41/1964)

(67) Pravilnik o tehničkim propisima za lake čelične građevine kod nosećih čeličnih konstrukcija (SL SFRJ, 6/1965)

(68) Pravilnik o tehničkim propisima za spojeve sa prenapregnutim vijcima kod nosećih čeličnih konstrukcija (SL SFRJ, 41/1964)

(69) Pravilnik o tehničkim propisima za pregled i ispitivanje nosećih čeličnih konstrukcija (SL SFRJ, 41/1964) 
(70) Pravilnik o tehničkim propisima za održavanje čeličnih konstrukcija za vrijeme eksploatacije kod nosećih čeličnih konstrukcija (SL SFRJ 41/1964)

(71) Pravilnik o tehničkim propisima za jednostavne konstrukcije zgrada kod nosećih čeličnih konstrukcija (SL SFRJ, 41/1964)

(72) Pravilnik o sredstvima osobne zaštite na radu i osobnoj zaštitnoj opremi (SL SFRJ, 15/1965)

(73) Pravilnik o tehničkim propisima za upotrebu rebrastog čelika za armirani beton (SL SFRJ, 39/1965, 16/1968)

(74) Pravilnik o općim mjerama i normativima zaštite na radu na oruđima i uređajima (SL SFRJ, 18/1967)

(75) Pravilnik o uvjetima za postavljanje radio-stanica (SL SFRJ, 23/1967, 55/1970)

(76) Pravilnik o minimalnim tehničkim uvjetima za izgradnju stanova (SL SFRJ, 45/1967)

(77) Pravilnik o tehničkim mjerama za upotrebu Bi-čelika u armiranobetonskim konstrukcijama (SL SFRJ, 18/1969, 20/1969, 14/1970)

(78) Pravilnik o tehničkim uvjetima za isporuku električne energije ( $S L$ SFRJ, 25/1969)

(79) Pravilnik o tehničkim mjerama i uvjetima za upotrebu mrežaste armature u armiranobetonskim konstrukcijama (SL SFRJ, 32/1969)

(80) Pravilnik o tehničkim mjerama za izgradnju skloništa za osnovnu zaštitu stanovništva (SL SFRJ, 15/1970)

(81) Pravilnik o tehničkim mjerama i uvjetima za izvođenje zidova zgrade (SL SFRJ, 17/1970)

(82) Pravilnik o tehničkim mjerama i uvjetima za izgradnju prostora i uređaja za prikupljanje i odnošenje otpadnih tvari iz stambenih zgrada (SL SFRJ, 28/1970)

(83) Pravilnik o tehničkim mjerama i uvjetima za toplotnu energiju u zgradama (SL SFRJ, 28/1970)

(84) Pravilnik o tehničkim mjerama i uvjetima za montažu čeličnih konstrukcija (SL SFRJ, 29/1970)

(85) Pravilnik o tehničkim mjerama i uvjetima za zaštitu čeličnih konstrukcija od korozije (SL SFRJ, 32/1970)

(86) Pravilnik o tehničkim mjerama i uvjetima za projektiranje i izvođenje betonskih i armiranobetonskih konstrukcija u sredinama izloženim agresivnom djelovanju vode i tla (SL SFRJ, 32/1970)

(87) Pravilnik o postavljanju i održavanju određenih poštanskih, telegrafskih, telefonskih i signalno-sigurnosnih postrojenja i uređaja na zemljištima i objektima u društvenom vlasništvu i vlasništvu građana (SL SFRJ, 34/1970) 
(88) Pravilnik o tehničkim mjerama i uvjetima za toplotnu zaštitu zgrada (SL SFRJ, 35/1970)

(89) Pravilnik o tehničkim mjerama i uvjetima za spregnute konstrukcije (SL SFRJ, 35/1970)

(90) Pravilnik o tehničkim mjerama i uvjetima za zvučnu zaštitu zgrada (SL SFRJ, 35/1970)

(91) Pravilnik o tehničkim mjerama i uvjetima za provjetravanje u stambenim zgradama (SL SFRJ, 35/1970)

(92) Pravilnik o tehničkim mjerama i uvjetima za završne radove u zgradarstvu (SL SFRJ, 49/1970)

(93) Pravilnik o tehničkim mjerama i uvjetima za dizala (SL SFRJ, 51/1970)

(94) Pravilnik o općim mjerama i normativima za zaštitu na radu od buke u radnim prostorijama (SL SFRJ, 29/1971)

(95) Pravilnik o tehničkim mjerama i uvjetima za prenapregnuti beton (SL SFRJ, 51/1971)

(96) Pravilnik o tehničkim mjerama i uvjetima za beton i armirani beton (SL SFRJ, 51/1971)

\section{E.1. Hrvatski republički pravilnici, uredbe i odluke 1950. - 1971.}

(97) Uredba o provođenju Zakona o urbanističkom i regionalnom prostornom planiranju (NN NRH, 41/1961)

(98) Pravilnik o ustupanju izgradnje investicionih objekata (NN NRH, 46/1963)

(99) Pravilnik o izdavanju odobrenja za izgradnju investicionih objekata (NN NRH, 46/1963)

(100) Pravilnik o tehničkom pregledu izgrađenih investicionih objekata (NN NRH, 46/1963)

(101) Odluka o određivanju investicionih objekata koji su od općeg interesa za Republiku (NN NRH, 47/1963)

\section{Objavljeni izvori}

ALEX: Österreichische Nationalbibliothek. Austria Lex. Historische Rechts- und Gesetzestexte:

- Reichs-, Staats- und Bundesgesetzblätter. Allgemeines Reichs-Gesetzund Regierungsblatt für das Kaiserthum Österreich [2. 12. 1848. - 31. 12. 1852.]. Reichs-Gesetz-Blatt für das Kaiserthum Österreich [4. 1. 1853. - 28. 12. 1869.]. Reichsgesetzblatt für die im Reichsrathe vertretenen Königreiche und Länder [1. 1. 1870. - 12. 11. 1918.]. Njemački jezik. Pristup ostvaren 4. 10. 2021. https:// alex.onb.ac.at/static_tables/tab_rgb.htm. 
- Reichsgesetzblatt Kroatisch. Allgemeines Reichs-Gesetz- und Regierungsblatt für das Kaiserthum Österreich [2. 12. 1848. - 31. 12. 1852.]. Reichsgesetzblatt für die im Reichsrathe vertretenen Königreiche und Länder [1. 1. 1870. - 12. 11. 1918.]. Hrvatski jezik. Pristup ostvaren 4. 10. 2021. https://alex.onb. ac.at/static_tables/tab_rsk.htm.

- Landesgesetzblätter für Dalmatien. Landesgesetz- und Regierungsblatt für das Kronland Dalamatien (sic!) [1848./49. - 1852.]. Landesregierungs-Blatt für Dalamatien (sic!) [1853. - 1859.]. Verordnungen der Landesbehörden für Dalamatien (sic!) [1860. - 1862.]. Gesetz- und Verordnungsblatt für Dalamatien (sic!) [1863. - 1867.]. Landes-Gesetz- und Verordnungsblatt für Dalmazien [1868. - 1888.]. Landes-Gesetz- und Verordnungsblatt für das Königreich Dalmatien [1889. - 1918.]. Njemački, hrvatski i talijanski jezik. Pristup ostvaren 4. 10. 2021. https://alex.onb.ac.at/static_tables/tab_lda.htm.

- Landesgesetzblätter für Kroatien und Slavonien. Landesgesetz- und Regierungsblatt für das Kronland Kroatien und Slavonien [1850. - 1852.]. Landesregierungsblatt für die Königreiche Kroatien und Slavonien [1853. - 1859.]. Verordnungen der Landesbehörden für die Königreiche Kroatien [1860. - 1918.]. Njemački i hrvatski jezik. Pristup ostvaren 4. 10. 2021. https://alex.onb.ac.at/ static_tables/tab_lks.htm.

- Landesgesetzblätter für Triest und das Küstenland. Landesgesetz- und Regierungsblatt für die reichsunmittelbare Stadt Triest und das Küstenland [1851. - 1852.]. Landes-Regierungs-Blatt für die Stadt Triest sammt Gebiet und das Küstenland [1853. - 1859.]. Verordnungen der Landesbehörden für das österreichisch-illirische Küstenland [1860. - 1862.]. Gesetze und Verordnungen der Landesbehörden für das österreichisch-illirische Küstenland (bestehend aus der gefürsteten Grafschaft Görz und Gradisca, der Markgrafschaft Istrien und der reichsunmittelbaren Stadt Triest mit ihrem Gebiet) [1863. - 1918.]. Njemački, slovenski i talijanski jezik. Pristup ostvaren 4. 10. 2021. https://alex.onb. ac.at/static_tables/tab_lkt.htm.

Memorandum of Understanding (with annexes and exchange of notes) regarding the Free Territory of Trieste. Signed at London, on 5 October 1954. Pristup ostvaren 7. 10. 2021. https://web.archive.org/web/20160305124801/http:// www.triestfreeport.org/wp-content/uploads/2010/09/Memorandum-of-Understandig-05.10.1954.pdf.

Narodne novine: službeni list Kraljevske banske uprave Savske banovine (Zagreb), 1930-1939.

Narodne novine: službeni list Banovine Hrvatske (Zagreb), 1939-1941.

Narodne novine: službeni list Federalne Hrvatske (Zagreb), 1945-1946.

Narodne novine: službeni list Narodne Republike Hrvatske (Zagreb), 19461963.

Narodne novine: službeni list Socijalističke Republike Hrvatske (Zagreb), 1963-1990. 
Narodne novine: službeni list Republike Hrvatske (Zagreb), 2013, 2015. Pristup ostvaren 6. 10. 2021. https://narodne-novine.nn.hr/search.aspx?sorti$\mathrm{raj}=4 \&$ kategorija $=1 \&$ godina $=1990 \& b r o j=31 \& \mathrm{rpp}=10 \& q$ type $=1 \&$ pretraga $=\mathrm{da}$.

Naše građevinarstvo (Beograd).

SISTORY [Arhiv Republike Slovenije]. Zgodovina Slovenije. Uradni listi. Uradni listi iz obdobja 1941-1945. Zakoni, zakonske odredbe i naredbe Nezavisne Države Hrvatske. Narodne novine: službeni list Države Hrvatske, 1-13 (1941); Službeni list Nezavisne Države Hrvatske, 14 (1941), 286 (1944). Pristup ostvaren 6. 10. 2021. https://www.sistory.si/11686/menu829.

Službene novine [Kraljevine Jugoslavije] (Beograd), 1931, 1937.

Službeni list Demokratske Federativne Jugoslavije (Beograd), 1945.

Službeni list Federativne Narodne Republike Jugoslavije (Beograd) 19451963.

Službeni list Socijalističke Federativne Republike Jugoslavije (Beograd), 1963-1992 [ne vrijedi na području Republike Hrvatske od 8. 10. 1991.].

\section{Literatura}

BENCETIĆ, Lidija. „Zagrebačka stanogradnja u prijedlozima planova i generalnim urbanističkim planovima od 1945. do 1990." Časopis za suvremenu povijest 52 (2020), br. 2: 389-418.

BOJIĆ, Živojin. „Odnos između građevinskog preduzeća i banke”. Naše građevinarstvo 6 (1952), br. 1-2: 53-56.

FURUNDŽIĆ, Božidar J.; FURUNDŽIĆ, Slobodan B., ur. Zbirka tehničkih propisa (tehničkih uslova, mera i normativa) u građevinarstvu, knj. 1. Beograd: Građevinska knjiga, ${ }^{4} 1980$.

GRAHEK RAVANČIĆ, Martina. „Razvoj pravosudnih vlasti i odgovarajućega pravnog okvira u Hrvatskoj 1945. godine". Časopis za suvremenu povijest 53 (2021), br. 1: 157-183.

JURIĆ, Zlatko. „Građevni redovi i regulatorno planiranje Zagreba od 1900. do 1918. godine". Časopis za suvremenu povijest 52 (2020), br. 1: 35-52.

KAHLE, Darko. „Architect Zlatko Neumann: Works after the Second World War (1945-1963)”. Prostor 24 (2016), br. 2: 172-187.

KAHLE, Darko. „Architectural Legislative Jurisdictions of the Banovina of Croatia (1939-1941) and the Independent State Of Croatia (1941-1945)". Priopćenje na međunarodnom znanstvenom skupu Art and the State in Modern Central Europe, Faculty of Humanities and Social Sciences, University of Zagreb, Zagreb, 30. 6. - 3. 7. 2021., 26.

KAHLE, Darko. „Fallout Shelters in Zagreb After the End of World War II". Izlaganje na međunarodnom znanstvenom skupu Society of Architectural Historians 2018 Annual International Conference, Saint Paul, MN, USA, 18. 22. 4. 2018. [neobjavljeno]. 
KAHLE, Darko. „Građevinski propisi grada Zagreba u razdoblju od 1850. do 1918. godine”. Prostor 12 (2004), br. 2: 203-215.

KAHLE, Darko. „Građevinski propisi za grad Zagreb u razdoblju od 1919. do 1931. godine i Građevinski zakon iz 1931. godine”. Prostor 14 (2006), br. 1: 116-129.

KAHLE, Darko. „Građevinski propisi za grad Zagreb u razdoblju od 1932. do 1945. godine”. Prostor 14 (2006), br. 2: 218-227.

KAHLE, Darko. „Rasprava 'Djelovanje potresa na zgrade' akademika Andrije Mohorovičića iz 1911. godine i protupotresna analiza građevnih propisa grada Zagreba u razdoblju od 1857. do 1964. godine”. Radovi Instituta za povijest umjetnosti 44/2 (2020): 29-42.

KAHLE, Darko. „The Architectural Office Vladimir Šterk in the Period 1923-1941". Prostor 26 (2018), br. 1: 20-39.

KALAFATOVIĆ, Dragaš. „Odnos: Investitor - izvođačko preduzeće”. Naše građevinarstvo 6 (1952), br. 1-2: 58-59.

KARAČ, Zlatko; BRAUN, Alan. „Analiza urbanističko-komunalnih i graditeljskih regula u srednjovjekovnom statutu grada Iloka iz 1525. godine”. Prostor 8 (2000), br. 1: 15-30.

KOVAČEVIĆ, Hranislav, ur. Zakon o ovlašćenim inženjerima: sa komentarom i dodatkom. Beograd: Službene novine, 1937.

KRANJČEVIĆ, Jasenka. „Ovlašteni arhitekti i strukovna udruženja u Dalmaciji do 1941. godine”. Kulturna baština 42-43 (2017): 207-228.

KRTALIĆ, Vladimir. Sustavi planiranja korištenja zemljišta - povijesni prikaz, postojeće stanje, prijedlog mogućeg oblikovanja hrvatskog sustava korištenja zemljišta. Zagreb: Novi informator, 2004.

KRSTIĆ, Branislav; PAJOVIĆ, Dušan, ur. Zakonodavstvo urbanizma, arhitekture, baštine, čovjekove sredine, prostornog uređenja. Beograd: Naučna knjiga, 1987.

MAROVIĆ, Fran; ATEVIĆ, Tomislav, ur. Zaštita od požara: izbor saveznih propisa s komentarom. Zagreb: Centar za informacije i publicitet, 1985.

MRČELA, Vladimir. „Neki aspekti odnosa ponuda i potražnje u stanogradnji Jugoslavije od 1945. do danas". Čovjek i prostor 28 (1981), br. 344: 1315.

NIKETIĆ, Gojko. Građevinski zakon: sa uredbama, propisima i normama za njegovo izvršenje. Drugo izdanje [НИКЕТИЋ, Гојко. Грађевински закон: са уредбама, прописима и нормама за юегово извршеюе. Друго издање]. Beograd: Izdavačka knjižarnica Gece Kona, 1932.

POP-KOCIĆ, Živojin, ur. Zbirka tehničkih propisa iz oblasti građevinarstva, knj. I. Beograd: Novinska ustanova Službeni list SFRJ, ${ }^{2} 1973$.

PRELOG, Milan. „Dubrovački statut i izgradnja grada (1272-1972)”. Peristil 14-15 (1971/72): 81-94. 
RUKAVINA, Marijan, ur. Zbirka najvažnijih propisa iz oblasti urbanizma i građevinarstva, sv. 3. Zagreb: Socijalistička Republika Hrvatska, Grad Zagreb, Sekretarijat za komunalne poslove građevinarstvo i saobraćaj, 1970.

SIMIĆ, Vasja. „Građevinska regulativa”. U: Tehnička enciklopedija, sv. 6, G-Ka. Zagreb: Leksikografski zavod „Miroslav Krleža”, 1979, 195-197.

SMREKAR, Milan. Priručnik za političku upravnu službu u kraljevinah Hrvatskoj i Slavoniji, knj. 3. Zagreb: Ignjat Granitz, 1902.

ŠILHARD, Vladimir. „Repetitorij građevnih propisa i procedure u N. R. Hrvatskoj". Čovjek i prostor 3 (1956), br. 52: 9-10.

TANDARIĆ, Neven; WATKINS, Charles; IVES, Cristopher D. „Urban planning in socialist Croatia / Urbano planiranje u Hrvatskoj tijekom socijalističkoga režima”. Hrvatski geografski glasnik 81 (2019), br. 2: 5-41.

ULRICH, Antun. „Trasiranje cesta za brzi promet”. Naše građevinarstvo 1 (1947), br. 3-4: 130-145.

„Uredba o ustrojstvu Ministarstva gradjevina”. Tehnički list 1 (1919), br. 2-3: 25-28.

VINCEKOVIĆ, Zoran; SESAR, Petar; ROUDNICKY, Edgar; JURIĆ, Smiljan, ur. Visokogradnja. Zbirka građevinskih propisa visokogradnje i niskogradnje za beton, drvo, čelik, mostogradnju sa kompletnim jugoslovenskim standardima, knj. 1-4. Beograd: Poslovna politika, 1990. 


\section{SUMMARY}

\section{Building and Town-Planning Regulations in Croatia from 1956 to 1971}

The building regulation system that was initiated in 1850 with the adoption of the 'Regulation on the Admission of Civil Engineering Students and the Introduction of State Examinations in Civil Engineering' in the Austrian Empire was repealed in 1946, through the 'Law on the Invalidity of Legal Regulations Adopted Before 6 April 1941 and During the Enemy Occupation'. The new socialist building regulation system was created through the regulations of the Yugoslav government from 1947 on; it was acceptable to use certain repealed regulations until new ones were enacted, provided they did not conflict with the newly-created socialist legal system of the Federal People's Republic of Yugoslavia. After the Federal Ministry of Construction was abolished in 1950, the technical regulations and standards were regulated at the federal level, while the administrative procedures and other legal regulations were gradually lowered to the level of the republics, including Croatia. So as to help architects, spatial planners, and other experts in the building process orient themselves in this jungle of regulations, architect Vladimir Šilhard (Schilchard) published the Revision Book of Building Regulations and Procedure in the P. R. of Croatia in the professional journal Covjek i prostor (Man and Space) in 1956. This article also exhaustively presents and analyses the building regulations in the period from 1946, through Šilhard's unified compendium, to the enactment of the Zagreb City Master Plan in 1971. On the one hand, the 1960s period was a great challenge for adopting regulations, primarily due to the new way of building residential buildings, which were not encompassed by the then existing regulations. On the other hand, new urban legislation was needed after Zagreb spread over the river Sava to the south, where the Zagreb Fair and the first residential neighbourhoods were built, so that the city could maintain a sustainable appearance of modernity. In this sense, the master plan of 1971 represented the peak of city planning that had begun with a competition for the for the General Regulatory Basis in 1930-1931 and the enactment of the Building Regulations of 1940. The system of technical regulations and building regulation standards on the federal level was mostly complete by late 1971, and remained partially in force even after the Republic of Croatia declared its independence on 8 October 1991, lasting until Croatia joined the European Union on 1 July 2013.

Key words: building legislation; building codes; urban planning regulations; Croatia; Zagreb; 1956-1971; building regulations 